University of Florida Levin College of Law

UF Law Scholarship Repository

Fall 2019

Wither Zauderer, Blossom Heightened Scrutiny? How the Supreme Court's 2018 Rulings in Becerra and Janus Exacerbate Problems with Compelled-Speech Jurisprudence

Clay Calvert

University of Florida Levin College of Law, profclaycalvert@gmail.com

Follow this and additional works at: https://scholarship.law.ufl.edu/facultypub

Part of the First Amendment Commons

Recommended Citation

Clay Calvert, Wither Zauderer, Blossom Heightened Scrutiny? How the Supreme Court's 2018 Rulings in Becerra and Janus Exacerbate Problems with Compelled-Speech Jurisprudence, 76 Wash. \& Lee L. Rev. 1395 (2019)

This Article is brought to you for free and open access by the Faculty Scholarship at UF Law Scholarship Repository. It has been accepted for inclusion in UF Law Faculty Publications by an authorized administrator of UF Law Scholarship Repository. For more information, please contact kaleita@law.ufl.edu. 


\title{
Wither Zauderer, Blossom Heightened Scrutiny? How the Supreme Court's 2018 Rulings in Becerra and Janus Exacerbate Problems with Compelled-Speech Jurisprudence
}

\author{
Clay Calvert*
}

\begin{abstract}
This Article examines how the United States Supreme Court's 2018 decisions in the First Amendment cases of National Institute of Family \& Life Advocates v. Becerra and Janus v. American Federation of State, County, \& Municipal Employees, Council 31, muddle an already disorderly compelled-speech doctrine. Specifically, dual five-to-four decisions in Becerra and Janus raise key questions about the level of scrutiny-either a heightened test or a deferential variant of rational basis review-against which statutes compelling expression should be measured. Critically, Becerra illustrates the willingness of the Court's conservative Justices to narrowly confine the aging compelled-speech test from Zauderer v. Office of Disciplinary Counsel. Furthermore, the Article explores how Justice Clarence Thomas's concurrence in a third 2018 decision-Masterpiece Cakeshop, Ltd. v. Colorado Civil Rights Commission-heightens problems with the compelled-speech doctrine. The Article concludes by proposing multiple criteria for the Court to consider

* Professor \& Brechner Eminent Scholar in Mass Communication and Director of the Marion B. Brechner First Amendment Project at the University of Florida in Gainesville, Fla. B.A., 1987, Communication, Stanford University; J.D. (Order of the Coif), 1991, McGeorge School of Law, University of the Pacific; Ph.D., 1996, Communication, Stanford University. The author thanks Olivia Baruch, Jessie Goodman, Joel Kratt, Erin McLoughlin, Carolina Panduro, Michelle Sebastian, Kevya Sims, and Emerson Tyler of the University of Florida for their helpful reviews of drafts of this Article.
\end{abstract}


when determining the level of scrutiny to use in compelled-speech cases.

\section{Table of Contents}

I. Introduction

II. Compelled Speech and the Chasm Dividing the Justices: Examining Becerra and Janus and

Their Impact on Zauderer

A. National Institute of Family \& Life Advocates v. Becerra 1406

B. Janus v. American Federation of State, County, \& Municipal Employees, Council 31

III. Digging Deeper into Justice Thomas's Views on Compelled Speech: His Masterpiece Cakeshop

Concurrence

IV. Conclusion

\section{Introduction}

The unenumerated First Amendment ${ }^{1}$ right not to speak, ${ }^{2}$ sometimes called "the First Amendment freedom from compelled expression,"3 once was readily understood. Viewed by the United

1. The First Amendment to the U.S. Constitution provides, in pertinent part, that "Congress shall make no law ... abridging the freedom of speech, or of the press...." U.S. Const. amend. I. The Free Speech and Free Press Clauses were incorporated nearly ninety-five years ago through the Fourteenth Amendment Due Process Clause as fundamental liberties to apply to state and local government entities and officials. See Gitlow v. New York, 268 U.S. 652, 666 (1925) ("[W]e may and do assume that freedom of speech and of the press are among the fundamental personal rights and 'liberties' protected by the due process clause of the Fourteenth Amendment . . ..”).

2. See Ashcroft v. Free Speech Coal., 535 U.S. 234, 245 (2002) ("As a general principle, the First Amendment bars the government from dictating what we see or read or speak or hear." (emphasis added)), superseded on other grounds by statute, Pub. L. No. 108-21, 117 Stat. 650 (2003); see also Wooley v. Maynard, 430 U.S. 705, 714 (1977) ("The right to speak and the right to refrain from speaking are complementary ....”).

3. Howard M. Wasserman, Compelled Expression and the Public Forum Doctrine, 77 TuL. L. REV. 163, 168 (2002). 
States Supreme Court "as part and parcel of the freedom of speech," 4 it was rooted in a handful of cases. ${ }^{5}$ Each was factually different, but generally extended "robust protection for a right not to speak." 6

For example, in 1943 the Supreme Court concluded in West Virginia State Board of Education v. Barnette ${ }^{7}$ that public school students cannot be forced to pledge allegiance to the United States and to engage in the symbolic expression ${ }^{8}$ of saluting the American flag. ${ }^{9}$ Justice Robert Jackson famously explained in Barnette that "[i]f there is any fixed star in our constitutional constellation, it is that no official, high or petty, can prescribe what shall be orthodox in politics, nationalism, religion, or other matters of opinion or force citizens to confess by word or act their faith therein."10 This precept, Professor Joseph Blocher notes, is now "a pillar of First Amendment jurisprudence... despite the fact that the amendment's text says nothing specifically about a right or freedom not to speak."11

Later, in its 1977 ruling in Wooley $v$. Maynard, ${ }^{12}$ the Court made it clear that a state cannot compel individuals to display mottos on government-required license plates that are

4. Scott W. Gaylord \& Thomas J. Molony, Casey and a Woman's Right to Know: Ultrasounds, Informed Consent, and the First Amendment, 45 Conn. L. REV. 595, 618 (2012).

5. See cases cited infra notes 7-19 (analyzing the Supreme Court's early First Amendment jurisprudence).

6. Abner S. Greene, "Not in My Name” Claims of Constitutional Right, 98 B.U. L. REV. 1475, 1486 (2018).

7. 319 U.S. 624 (1943).

8. See id. at 632

There is no doubt that, in connection with the pledges, the flag salute is a form of utterance. Symbolism is a primitive but effective way of communicating ideas. The use of an emblem or flag to symbolize some system, idea, institution, or personality, is a short cut from mind to mind.

9. See id. at 642 ("We think the action of the local authorities in compelling the flag salute and pledge transcends constitutional limitations on their power and invades the sphere of intellect and spirit which it is the purpose of the First Amendment to our Constitution to reserve from all official control.").

10. Id.

11. Joseph Blocher, The Right Not to Keep or Bear Arms, 64 STAN. L. REV. 1,19 (2012).

12. 430 U.S. 705 (1977). 
"repugnant to their moral and religious beliefs."13 The Court ruled in favor of a husband and wife who were Jehovah's Witnesses and who objected on "moral, religious, and political" grounds to conveying New Hampshire's state motto of "Live Free or Die" on their automobile's license plate. ${ }^{14}$ In brief, as Professor Mark Strasser writes, "Barnette and Wooley both stand for the proposition that the First Amendment protects the right not to speak under certain conditions ...."15

Additionally, the Court in Miami Herald Publishing Co. v. Tornillo ${ }^{16}$ specified forty-five years ago that newspapers are not obligated to print editorial content to which they object. ${ }^{17}$ Furthermore, in its 1995 ruling in Hurley v. Irish-American Gay, Lesbian \& Bisexual Group, ${ }^{18}$ the Court held that private citizens who organize parades cannot be required by the government to

13. Id. at 707 .

14. See id. at 707 n.2 (describing Mr. Maynard's objections to the state motto: "I believe that life is more precious than freedom").

15. Mark A. Strasser, What's Fair for Conscientious Objectors Subject to Public Accommodations Laws, 48 N.M. L. REV. 124, 134 (2018). Strasser points out, however, that both Barnette and Wooley

involved government-prescribed speech, so their applicability in contexts where the government is not specifying contents of others' speech is an open question. It is simply unclear whether an important aspect of the right not to speak jurisprudence is that an individual is being asked to expressly affirm something contrary to his or her belief.

Id. at $134-35$.

16. 418 U.S. 241 (1974).

17. In striking down a Florida right-of-reply statute that granted political candidates free space in newspapers in the Sunshine State that had criticized or attacked their records, the Court reasoned:

A newspaper is more than a passive receptacle or conduit for news, comment, and advertising. The choice of material to go into a newspaper, and the decisions made as to limitations on the size and content of the paper, and treatment of public issues and public officials-whether fair or unfair-constitute the exercise of editorial control and judgment. It has yet to be demonstrated how governmental regulation of this crucial process can be exercised consistent with First Amendment guarantees of a free press as they have evolved to this time.

Id. at 258 .

18. 515 U.S. 557 (1995). 
include in them "a group imparting a message the organizers do not wish to convey." 19

Such cases individually are somewhat simple to understand. Yet as Professor Nat Stern contended in 2011, "the right to resist governmentally imposed expressive activities has evolved into a sprawling and ungainly doctrine."20 That is largely because the right not to speak has been "[i]nvoked in efforts to thwart requirements ranging from acceptance of military recruiters at law school campuses to subsidies for generic advertising of agricultural products ...." ${ }^{21}$ If it was true eight years ago that the right not to speak had "lost much of its coherence," 22 then facets of three 2018 Supreme Court rulings-National Institute of Family \& Life Advocates $v$. Becerra, ${ }^{23}$ Janus v. American Federation of State, County, \& Municipal Employees, Council $31,{ }^{24}$ and Masterpiece Cakeshop, Ltd. v. Colorado Civil Rights Commission ${ }^{25}$ _further clouded the murky waters.

In Becerra, a conservative five-Justice majority ${ }^{26}$ held that two compelled-speech obligations affecting religiously affiliated anti-abortion crisis pregnancy centers $^{27}$ in California likely violated the First Amendment. ${ }^{28}$ One provision mandated that

19. Id. at 559 .

20. Nat Stern, The Subordinate Status of Negative Speech Rights, 59 BuFF. L. REV. 847, 849 (2011).

21. Id.

22. $I d$.

23. 138 S. Ct. 2361 (2018).

24. 138 S. Ct. 2448 (2018).

25. 138 S. Ct. 1719 (2018).

26. Justice Clarence Thomas authored the majority opinion and was joined by Chief Justice John Roberts and Justices Anthony Kennedy, Samuel Alito, and Neil Gorsuch. See Becerra, 138 S. Ct. at 2367 (identifying the Justices who joined Thomas in delivering the Court's opinion).

27. See Adam Liptak, Anti-Abortion Health Clinics Win First Amendment Ruling, N.Y. Times, June 27, 2018, at A1 (describing the centers as "religiously oriented" facilities that "oppose abortion on religious grounds"); see also Adam Liptak, Skepticism by the Court for a Law that Requires a Discussion of Abortion, N.Y. TIMES, Mar. 21, 2018, at A13 ("The centers, which are often affiliated with religious groups, seek to persuade women to carry their pregnancies to term or to offer their offspring for adoption.").

28. See Becerra, 138 S. Ct. at 2378 ("We hold that petitioners are likely to succeed on the merits of their claim that the FACT Act violates the First Amendment."). 
licensed crisis pregnancy centers ${ }^{29}$ notify women that California offers free and low-cost abortion services. ${ }^{30}$ The other required unlicensed centers ${ }^{31}$ to post the following message: "This facility is not licensed as a medical facility by the State of California and has no licensed medical provider who provides or directly supervises the provision of services." 32 Justice Stephen Breyer, joined by fellow liberal-leaning Justices Ruth Bader Ginsburg, Sonia Sotomayor, and Elena Kagan, dissented and declared both provisions "likely constitutional." 33

In Janus, the same five-Justice majority that aligned in Becerra declared unconstitutional an Illinois statute ${ }^{34}$ compelling public employees who are not union members to pay an agency fee to the union that exclusively bargains on their behalf. ${ }^{35}$ Penning the majority opinion in Janus, Justice Samuel Alito wrote that "this arrangement violates the free speech rights of nonmembers by compelling them to subsidize private speech on matters of substantial public concern." 36 In reaching this conclusion-and of particular importance to this Article-Alito opined that "measures compelling speech are at least as threatening" 37 as those squelching speech and, in fact, may cause "additional damage." 38 Writing for the same bloc of dissenters as

29. See Cal. Health \& SAFEty Code $§ 123471$ (a) (West 2016) (setting forth the criteria for a licensed center).

30. Id. $\S 123472(\mathrm{a})(1)$.

31. See id. $\S 123471$ (b) (setting forth the criteria for an unlicensed center).

32. Id. $\S 123472(\mathrm{~b})(1)$.

33. See Becerra, 138 S. Ct. at 2379-80 (Breyer, J., dissenting) (arguing that because "most human behavior takes place through speech" and because much of the law regulates that speech in terms of its content, the majority's approach "at least threatens considerable litigation over the constitutional validity of much, perhaps most, government regulation").

34. See 5 ILl. Comp. Stat. 315/6(e) (2018) (providing that agency fees are chargeable to non-union members for union activities including "the costs of the collective bargaining process, contract administration and pursuing matters affecting wages, hours and conditions of employment").

35. Janus v. Am. Fed'n State, Cty., \& Mun. Emps., Council 31, 138 S. Ct. 2448, 2460 (2018).

36. Id.

37. Id. at 2464 .

38. See id. (explaining that when speech is compelled, individuals "are coerced into betraying their convictions" and are demeaned by being forced to endorse ideas that they find objectionable). 
in Becerra, Justice Kagan blasted the majority both for "turning the First Amendment into a sword, and using it against workaday economic and regulatory policy" 39 and for broadly contending "that compelling speech always works a greater injury, and so always requires a greater justification.” ${ }_{40}$

Finally, the Court in Masterpiece Cakeshop held that the Colorado Civil Rights Commission violated the First Amendment's Free Exercise Clause ${ }^{41}$ rights of a baker because it failed to act with "religious neutrality" in punishing him for violating a state anti-discrimination statute. ${ }^{42}$ The baker, Jack Phillips, was "a devout Christian" who refused to create a cake celebrating the marriage of a same-sex couple "because of his religious opposition to same-sex marriage." 43

Although Justice Anthony Kennedy's opinion for the Court dodged the First Amendment free speech issue, Justice Clarence Thomas issued a concurrence addressing it. ${ }^{44}$ Thomas initially concluded that making a custom wedding cake constitutes expressive conduct protected by the First Amendment. ${ }^{45}$ He then found that being forced to produce such a cake for a same-sex wedding under Colorado's anti-discrimination statute amounted to a compelled-speech obligation that would violate the First

39. Id. at 2501 (Kagan, J., dissenting).

40. Id. at 2494.

41. The First Amendment to the U.S. Constitution provides, in pertinent part, that "Congress shall make no law respecting an establishment of religion, or prohibiting the free exercise thereof ...." U.S. ConsT. amend. I. The Free Exercise Clause was incorporated nearly eighty years ago through the Fourteenth Amendment Due Process Clause as a fundamental liberty to apply to state and local government entities and officials. See Cantwell v. Connecticut, 310 U.S. 296, 303 (1940) (noting that the Fourteenth Amendment embraces First Amendment liberties).

42. See Masterpiece Cakeshop, Ltd. v. Colo. Civil Rights Comm'n, 138 S. Ct. 1719, 1724, 1731 (2018) (concluding that "the Commission's treatment of Phillips' case violated the State's duty under the First Amendment not to base laws or regulations on hostility to a religion or religious viewpoint").

43. Id.

44. See id. at 1740 (Thomas, J., concurring) ("While Phillips rightly prevails on his free-exercise claim, I write separately to address his free-speech claim.").

45. See id. at 1743-44 (explaining that a wedding cake symbolizes the celebration of a new marriage and, thus, communicates a message). 
Amendment's protection of free speech unless it could survive the strict scrutiny standard of review. ${ }^{46}$

How Becerra, Janus, and Masterpiece Cakeshop affect the First Amendment right not to speak is the focus of this Article as well as the decisions' impact on the Court's 1985 ruling in Zauderer $v$. Office of Disciplinary Counsel. ${ }^{47}$ The Court in Zauderer considered whether the government can lawfully "prevent potential deception of the public by requiring attorneys to disclose in their advertising certain information regarding fee arrangements." 48 Specifically, Ohio compelled attorneys using contingency fee arrangements to disclose to clients that they may need to pay litigation costs if they lose their cases. ${ }^{49}$ The Court emphasized that Ohio compelled only "purely factual and uncontroversial information about the terms under which [an attorney's] services will be available." 50

In upholding this requirement, the Court distinguished the above-noted cases of Barnette, Wooley, and Tornillo. ${ }^{51}$ In particular, that trio of decisions did not involve commercial speech, which is protected by the First Amendment primarily because of its "value to consumers." 52 The Court in Zauderer thus held "that an advertiser's rights are adequately protected as long as disclosure requirements are reasonably related to the State's interest in preventing deception of consumers." ${ }_{53}$ The Court added that while such disclosure requirements cannot be "unduly burdensome," ${ }_{4}$ they need not be the least restrictive means of

46. See id. at 1745-46 ("Because Phillips' conduct... was expressive, Colorado's public-accommodations law cannot penalize [the conduct] unless the law withstands strict scrutiny."); see also infra note 59 and accompanying text (describing strict scrutiny).

47. 471 U.S. 626 (1985).

48. Id. at 629 .

49. See id. at 633 ("DR 2-101(B)(15) . . provides that any advertisement that mentions contingent-fee rates must 'disclose whether percentages are computed before or after deduction of court costs and expenses ....”').

50. Id. at 651.

51. See id. ("[T]he interests at stake in this case are not of the same order as those discussed in Wooley, Tornillo, and Barnette.").

52. See id. (discussing the consumer-focused considerations surrounding First Amendment protection of commercial speech).

53. Id.

54. Id. 
serving the state's interest in preventing deception. ${ }^{55}$ Additionally, the government need not worry about an underinclusivity challenge. ${ }^{56}$

The Zauderer standard approximates a lenient, rational basis test ${ }^{57}$ rather than a heightened level of judicial review-like intermediate scrutiny ${ }^{58}$ or strict scrutiny ${ }^{59}$ - even though the

55. See id. at 651 n.14 ("We reject appellant's contention that we should subject disclosure requirements to a strict 'least restrictive means' analysis under which they must be struck down if there are other means by which the State's purposes may be served.").

56. Here, the Court wrote:

[W]e are unpersuaded by appellant's argument that a disclosure requirement is subject to attack if it is "under-inclusive"- that is, if it does not get at all facets of the problem it is designed to ameliorate. As a general matter, governments are entitled to attack problems piecemeal, save where their policies implicate rights so fundamental that strict scrutiny must be applied.

Id.; see generally Clay Calvert, Underinclusivity and the First Amendment: The Legislative Right to Nibble at Problems After Williams-Yulee, 48 ARIZ. ST. L.J. 525 (2016) (providing a comprehensive review of the underinclusivity doctrine).

57. See Lili Levi, A "Faustian Pact"? Native Advertising and the Future of the Press, 57 ARIZ. L. REV. 647, 681 (2015) (opining that the test in Zauderer is "akin to rational basis review"); see also Katie R. Eyer, The Canon of Rational Basis Review, 93 Notre DAME L. REV. 1317, 1319 (2018) (asserting that "the canonical account of rational basis review is a bleak one for those challenging the constitutionality of government action: a doctrine which is extraordinarily deferential and will virtually never result in government action being overturned"); Brandon L. Garrett, Constitutional Reasonableness, 102 MinN. L. REV. 61, 64 (2017) (observing that "rational basis review ostensibly asks judges to deferentially review reasonable government decisions"); Cynthia Lee, Package Bombs, Footlockers, and Laptops: What the Disappearing Container Doctrine Can Tell Us About the Fourth Amendment, 100 J. CRIM. L. \& CRIMINOLOGY 1403, 1467 (2010) (suggesting that "courts engaging in equal protection rational basis review will invalidate social and economic legislation only if there is absolutely no rational explanation, real or imagined, for the legislation"); Stacey L. Sobel, The Tsunami of Legal Uncertainty: What's a Court to Do Post-McDonald?, 21 CORNELL J.L. \& PUB. POL'Y 489, 495 (2012) ("The lowest level of review is the rational basis test-a highly deferential form of scrutiny. In order for a regulation to survive rational basis review, the challenger must prove that the regulation does not bear a 'rational relationship' to a 'legitimate governmental purpose.").

58. Content-neutral regulations of speech typically are subject to intermediate scrutiny. See Packingham v. North Carolina, 137 S. Ct. 1730, 1736 (2017) (explaining that in order to survive intermediate scrutiny, North Carolina's content-neutral statute prohibiting sex offenders from accessing social networking sites "must be narrowly tailored to serve a significant governmental interest"). Under intermediate scrutiny, a statute "need not be the least restrictive or least intrusive means of" serving the alleged government 
Zauderer Court did not use rational basis terminology. ${ }^{60}$ In brief, while a version of intermediate scrutiny typically applies in commercial speech cases where the government suppresses speech, ${ }^{61}$ an even more lax standard from Zauderer applies when

interest in order to satisfy the "narrowly tailored" prong. Ward v. Rock Against Racism, 491 U.S. 781, 798 (1989).

59. Strict scrutiny "applies either when a law is content based on its face or when the purpose and justification for the law are content based." Reed v. Town of Gilbert, 135 S. Ct. 2218, 2228 (2015). Under this standard, laws are "justified only if the government proves that they are narrowly tailored to serve compelling state interests." Id. at 2226. Narrow tailoring under strict scrutiny, in turn, requires a statute to "be the least restrictive means" of serving the government's allegedly compelling interest. McCullen v. Coakley, 573 U.S. 464, 478 (2014). See Brown v. Entm't Merchs. Ass'n, 564 U.S. 786, 799 (2011) (observing that a statute that restricts "the content of protected speech" will pass strict scrutiny only if "it is justified by a compelling government interest and is narrowly drawn to serve that interest").

60. Former Yale Law School Dean Robert Post explains that

[b]ecause commercial speakers retain "minimal" First Amendment interests, Zauderer does not employ the specific vocabulary of "rational basis" review, which would have suggested extreme judicial deference. It instead adopts terminology that unequivocally locates judicial review further toward the deferential end of the spectrum than the intermediate scrutiny authorized by Central Hudson.

Robert Post, C. Edwin Baker Lecture for Liberty, Equality, and Democracy: Compelled Commercial Speech, 117 W. VA. L. REV. 867, 883 (2015).

61. The U.S. Supreme Court typically deploys a four-part test for commercial speech that requires courts to

determine whether the expression is protected by the First Amendment. For commercial speech to come within that provision, it at least must concern lawful activity and not be misleading. Next, [courts] ask whether the asserted governmental interest is substantial. If both inquiries yield positive answers, [courts] must determine whether the regulation directly advances the governmental interest asserted, and whether it is not more extensive than is necessary to serve that interest.

Cent. Hudson Gas \& Elec. Corp. v. Pub. Serv. Comm'n, 447 U.S. 557, 566 (1980); see also Lorillard Tobacco Co. v. Reilly, 533 U.S. 525, 572 (2001) (Thomas, J., concurring) (describing "the intermediate scrutiny of Central Hudson"); see also Levi, supra note 57, at 681 n.172 (discussing how Central Hudson created "a four-pronged standard of intermediate scrutiny for commercial speech" (emphasis added)); Tamara R. Piety, Market Failure in the Marketplace of Ideas: Commercial Speech and the Problem that Won't Go Away, 41 LoY. L.A. L. REV. 181, 182 (2007) (observing that "the commercial speech doctrine creates a category of speech subject to intermediate scrutiny under the First Amendment" (emphasis added)). 
it compels advertisers to disclose factual and noncontroversial information. ${ }^{62}$

With this background in mind, Part II of the Article examines both Becerra and Janus and how they affect the Court's compelled-speech jurisprudence and, more specifically, the level of scrutiny that applies to evaluate the constitutionality of compelled-speech mandates. Part II also explores crucial points of disagreement between the majority and dissent in Becerra over the scope of the Court's decades-old ruling in Zauderer. Part III then turns in greater detail to Justice Thomas's concurrence in Masterpiece Cakeshop, in which he elaborated on his views regarding compelled speech. Thomas's Masterpiece Cakeshop opinion merits separate analysis here because he penned the majority opinion just three weeks later in Becerra, which struck down a pair of compelled-speech obligations. ${ }^{63}$ Finally, Part IV concludes by proposing criteria for the Court to use when deciding the proper level of scrutiny in compelled-speech cases. Regardless of whether the Court adopts these variables, it is imperative for it to better articulate and then consistently apply its own standards for determining scrutiny in compelled-speech disputes. This would add predictability to this now jumbled niche of First Amendment jurisprudence and, in the process, enhance the Court's legitimacy that arguably is eroded when it fractures along perceived political lines in compelled-speech cases such as Becerra and Janus.

\section{Compelled Speech and the Chasm Dividing the Justices:}

Examining Becerra and Janus and Their Impact on Zauderer

This Part of the Article has two sections. Section A explores the Supreme Court's analysis of a compelled-speech obligation in National Institute of Family \& Life Advocates $v$. Becerra and how the majority and dissent disagreed about the applicable level of

62. See Zauderer v. Office of Disciplinary Counsel, 471 U.S. 626, 651 (1985) (stating that an advertiser's "constitutionally protected interest in not providing any particular factual information in his advertising is minimal").

63. Compare Masterpiece Cakeshop, Ltd. v. Colo. Civil Rights Comm'n, 138 S. Ct. 1719 (2018) (case decided on June 4, 2018), with Nat'l Inst. of Family \& Life Advocates v. Becerra, 138 S. Ct. 2361 (2018) (case decided on June 26, 2018). 
scrutiny. Section B then assesses the Court's discussion of compelled speech in Janus $v$. American Federation of State, County, \& Municipal Employees and the similar clash over scrutiny in Janus.

\section{A. National Institute of Family \& Life Advocates v. Becerra}

As noted above, Becerra concerned the constitutionality of a California law compelling speech at both licensed and unlicensed crisis pregnancy centers. ${ }^{64}$ For simplicity's sake, this section focuses on the obligation at licensed centers to inform women that "California has public programs that provide immediate free or low-cost access to comprehensive family planning services (including all FDA-approved methods of contraception), prenatal care, and abortion for eligible women." ${ }^{5}$ This message had to be conveyed either by being posted in a conspicuous place in a facility's waiting room or by being given individually in print or digital form to all clients. ${ }^{66}$

California enacted this measure-called the FACT Act-to educate women about "their rights and the health care services available to them." 67 The compelled-speech obligation was essential because, according to the state, "thousands of women" are unaware of public programs relating to abortion services. ${ }^{68}$ Additionally, the state contended that delivery of the message about abortion services at crisis facilities was critical because of the "time sensitive nature of pregnancy-related decisions."69

In short, California's rationale taps into what Professor Burt Neuborne calls "a hearer's First Amendment right to know"70 about "information and ideas that will assist the hearer in

64. See supra notes 26-33 and accompanying text (providing an overview of the laws at issue in Becerra, as well as the Court's decision in the case).

65. CAL. Health \& SAFETy Code $§ 123472$ (a)(1) (West 2016).

66. See id. $\S 123472$ (a)(2)(A)-(C) (listing the three ways through which the information may be distributed).

67. Becerra, 138 S. Ct. at 2369.

68. See id. (describing the state legislature's motivation in enacting the measure).

69. Id.

70. Burt Neuborne, The Status of the Hearer in Mr. Madison's Neighborhood, 25 WM. \& MARY BILL RTS. J. 897, 906 (2017). 
making rational, informed choices, whether economic, social, aesthetic, or political."71 Although the Supreme Court has acknowledged in dicta the existence of a First Amendment right to receive speech, ${ }^{72}$ Neuborne notes that the Court generally "has not . . . developed the right to know beyond the slogan stage." 73

Before delving into Becerra's majority and dissenting opinions, it is useful to pinpoint precisely what California's law did and did not do. Specifically, the compelled-speech mandate for licensed centers might be considered a pure disclosure-of-factual-information obligation. ${ }^{74}$ Unlike the seminal right-not-to-speak cases of Barnette and Wooley, California did not compel the centers to express a viewpoint, adopt a position, or convey a state-sponsored philosophy, maxim, or creed.75 Additionally, and in contrast with Tornillo, in which Florida required newspapers in the Sunshine State to print the views of political candidates who those newspapers criticized or attacked, ${ }^{76}$ licensed centers were not forced to publish noxious political views or positions. ${ }^{77}$ California's law thus was not what might be characterized as an expression-of-viewpoint compelled-speech obligation. ${ }^{78}$

71. Id. at $906-07$.

72. See Griswold v. Connecticut, 381 U.S. 479, 482 (1965) (asserting that the "freedom of speech and press includes," among other things, "the right to receive" speech); see also Pac. Gas \& Elec. Co. v. Pub. Utilities Comm'n, 475 U.S. 1, 8 (1986) ("By protecting those who wish to enter the marketplace of ideas from government attack, the First Amendment protects the public's interest in receiving information.").

73. Neuborne, supra note 70, at 907.

74. See supra notes 47-56 and accompanying text (distinguishing Zauderer's commercial speech conveying factual information from other forms of compelled speech).

75. See Nat'l Inst. of Family \& Life Advocates v. Becerra, 138 S. Ct. 2361, 2368-70 (2018) (describing the law's factual, information-based disclosure requirements).

76. See Miami Herald Publ'g Co. v. Tornillo, 418 U.S. 241, 243 (1974) ("The issue in this case is whether a state statute granting a political candidate a right to equal space to reply to criticism and attacks on his record by a newspaper violates the guarantees of a free press.").

77. See Becerra, 138 S. Ct. at 2371 (characterizing the notice's content as "the availability of state-sponsored services, as well as contact information for how to obtain them").

78. Compare id., with Janus v. Am. Fed'n State, Cty., \& Mun. Emps., 138 S. Ct. 2448, 2459-60 (2018) (explaining that mandatory labor union fees are 
Additionally, California's law targeting licensed centers was not what might be dubbed a prevention-of-deception compelled-speech obligation. ${ }^{79}$ It was not, in other words, designed to correct information conveyed at licensed centers that might be false or misleading. Rather, as California lawmakers put it, the measure was intended to "ensure that California residents make their personal reproductive health care decisions knowing their rights and the health care services available to them." 80 The obligation thus might-positively put-be called a knowledge-enhancement compelled-speech mandate or-negatively parsed-a correction-of-ignorance duty. ${ }^{81}$ One might query whether a state has a greater interest in compelling speech to prevent deception or to enhance knowledge or, alternatively, whether compelling speech in the name of those two interests is of equal importance when evaluating the constitutionality of a compelled-speech statute.

Furthermore, California's law might also be classified as a message-diluting or message-adulterating compelled-speech obligation. ${ }^{82}$ That is because, by being forced to convey facts about a procedure to which the speaker (i.e., a licensed crisis pregnancy center) objects and, in turn, to convey facts that might (because they specify that abortion services are offered free and at low-cost) lead a patient to adopt that procedure, the power of the speaker's own message in favor of not terminating pregnancy is arguably diminished. ${ }^{83}$ Put differently, a licensed crisis pregnancy center with an anti-abortion stance might find that its message's influence is mitigated (or at least contaminated) by

viewpoint-based compelled speech).

79. See, e.g., Zauderer v. Office of Disciplinary Counsel, 471 U.S. 626, 651 (1985) (recognizing the state's legitimate interest in "preventing deception of consumers").

80. Becerra, 138 S. Ct. at 2369.

81. See Semler v. Oregon State Bd. of Dental Examiners, 294 U.S. 608, 611 (1935) ("The state may ... afford protection against ignorance, incapacity, and imposition."); see also In re R.M.J., 455 U.S. 191, 202 (1982) (recognizing the state's interest in controlling advertising for professional services due to "the public's comparative lack of knowledge").

82. See Becerra, 138 S. Ct. at 2371 (discussing the effect of content-based speech regulations that undermine the speaker's message).

83. See id. (describing that a mandatory notice promoting state-subsidized abortions "alters the content" of the clinic's anti-abortion speech). 
transmitting a fact suggesting that one's financial status imposes no barrier to obtaining an abortion. ${ }^{84}$

This Article returns in the Conclusion to some of the italicized labels used immediately above for characterizing compelled-speech laws. Specifically, the labels are melded into the criteria the Conclusion proposes for courts to use when deciding the proper level of scrutiny in compelled-speech cases. ${ }^{85}$ Indeed, a vital issue - and a point of dispute between the majority and dissent-in Becerra was the standard of scrutiny the Court should apply to the compelled-speech obligation imposed on licensed crisis pregnancy centers. ${ }^{86}$

In an opinion written by Justice Clarence Thomas, the majority concluded that because the measure was content-based, ${ }^{87}$ strict scrutiny ${ }^{88}$ should apply unless the case either fit within the confines of Zauderer ${ }^{89}$ or involved the regulation "of professional conduct that incidentally burden[ed] speech."90 The majority not only determined that neither exception applied, ${ }^{91}$ but also found that the law could not pass muster even under intermediate scrutiny because it was not narrowly tailored to serve what the majority assumed was a substantial interest in "providing low-income women with information about state-sponsored services." ${ }^{2}$

84. See id. (acknowledging the conflict between providing information for abortion services while simultaneously trying to "dissuade women from choosing that option").

85. See discussion infra Part IV (taking a holistic approach and articulating multiple variables for considering the proper level of scrutiny in compelled-speech cases).

86. See Nat'l Inst. of Family \& Life Advocates v. Becerra, 138 S. Ct. 2361, 2382-83 (2018) (Breyer, J., dissenting) (disagreeing with the majority's decision to apply a heightened standard of scrutiny).

87. See id. at 2365 (majority opinion) (reasoning that the notices were content-based regulations because they compelled petitioners to speak a particular message, thus "alter[ing] the content of their speech").

88. See supra note 59 and accompanying text (describing strict scrutiny).

89. See supra notes 47-62 and accompanying text (describing Zauderer and the test the Court fashioned in it).

90. Becerra, 138 S. Ct. at 2373.

91. See id. at 2372-73 (describing each exception and concluding that neither applied).

92. Id. 
In rejecting application of the Zauderer test, the majority limited that test to situations in which the compelled speech relates to services provided by the regulated entity or individual. ${ }^{93}$ Because crisis pregnancy centers do not offer abortions, Zauderer did not apply. ${ }^{94}$

Moreover, the majority reasoned that Zauderer only concerns situations involving compelled speech about uncontroversial topics. ${ }^{95}$ Thomas opined that abortion is "anything but an 'uncontroversial' topic."96 This, however, cleverly contorts Zauderer's actual language. Zauderer mentioned "uncontroversial information," 97 not an uncontroversial topic. Additionally, and problematically, what constitutes a "controversial" topic is subjective, and Thomas offered no guidance for how it might be established. ${ }^{98}$

The majority also rejected the argument that California's law primarily regulated professional conduct and only incidentally burdened speech. ${ }^{99}$ Becerra was not, Justice Thomas reasoned, an informed-consent case in which the government mandated speech incidental to a procedure performed by a professional. ${ }^{100}$ In other words, because licensed crisis pregnancy centers do not themselves perform abortions, the speech California required was

93. See id. at 2372 ("The notice in no way relates to the services that licensed clinics provide. Instead, it requires these clinics to disclose information about state-sponsored services-including abortion . . ..”).

94. See id. (acknowledging that abortion is one such service that the licensed clinics do not provide and clarifying that Zauderer applies only in the context of professionals advertising their own services).

95. See id. (explaining that the disclosures in Zauderer were upheld because they contained "purely factual and uncontroversial information").

96. Id.

97. Zauderer v. Office of Disciplinary Counsel, 471 U.S. 626, 651 (1985) (emphasis added).

98. Nat'l Inst. of Family \& Life Advocates v. Becerra, 138 S. Ct. 2361, 2372 (2018) (opining that abortion is "anything but" an uncontroversial topic without justifying his assertion).

99. See id. at 2373-74 (concluding that the licensed notice does not regulate professional conduct because it applies to "all interactions between a covered facility and its clients, regardless of whether a medical procedure is ever sought, offered, or performed").

100. See id. (suggesting that Becerra falls short of the line "long familiar to the bar" between conduct and speech-only the former of which can be heavily regulated). 
untethered from any conduct. 101 Thomas therefore concluded that instead of being incidental to conduct, the "licensed notice regulates speech as speech" and requires heightened scrutiny. ${ }^{102}$

The majority in Becerra, however, suggested two other circumstances when compelled-speech requirements are permissible, including when the message: 1) consists "of health and safety warnings long considered permissible,"103 or 2) involves "purely factual and uncontroversial disclosures about commercial products." 104 Regarding the former circumstance, the majority failed to clarify for precisely how long a health and safety warning must have both existed and been considered permissible before it falls within this exception. ${ }^{105}$ Additionally, Thomas did not articulate when a warning implicates "health and safety" concerns. ${ }^{106}$ As for the latter exception, it seemingly extends Zauderer from the realm of services offered by attorneys and doctors to the domain of products sold commercially. ${ }^{107}$

In summary, the Becerra majority held that content-based, compelled-speech regulations must surmount heightened scrutiny unless one of four exceptions applies. ${ }^{108}$ Those exceptions arise when the compelled speech:

101. See id. at 2373 ("The notice does not facilitate informed consent to a medical procedure. In fact, it is not tied to a procedure at all.").

102. See $i d$. at 2372-74 (stating that "neither line of precedents" applying to "purely factual and uncontroversial information" or to notices that "regulat[e] ... professional conduct" would lessen the standard of scrutiny in this case).

103. Id. at 2376 .

104. Id.

105. See id. at 2381 (Breyer, J., dissenting) ("The majority . . . does not explain why the [FACT] Act here, which is justified in part by health and safety considerations, does not fall within its 'health' category.").

106. See id. at 2376 (majority opinion) (stating the legality of "health and safety warnings" without defining a standard to determine whether a disclosure falls into that category).

107. Compare Zauderer, 471 U.S. at 561-62, 655 (upholding the State of Ohio's requirement that an attorney offering services on a contingent fee basis disclose that clients would have to pay costs even in an unsuccessful lawsuit), with Becerra, 138 S. Ct. at 2376 (indicating that "purely factual and uncontroversial disclosures about commercial products" fall under the Zauderer exception for compelled speech (emphasis added)).

108. See cases cited infra notes 109-112 and accompanying text (summarizing the exceptions to the heightened scrutiny standard for compelled speech designated by the Becerra majority). 
1) is purely factual, pertains to services rendered directly by the regulated entity or individual, and relates to an uncontroversial topic; 109 or

2) is merely incidental to conduct (a procedure) performed by a professional; 110 or

3) consists of warnings affecting health and safety, and those warnings have been considered permissible for a long period of time; ${ }^{111}$ or

4) relates to commercial products and conveys factual and uncontroversial information about them. ${ }^{112}$

Of particular importance from a free-speech theory perspective, the majority invoked the venerable marketplace of ideas metaphor ${ }^{113}$ to illustrate the supposed danger of California imposing its compelled-speech obligation on licensed facilities and show why strict scrutiny must apply. ${ }^{114}$ The marketplace theory, in a nutshell, comports with "the idea that freedom of speech serves as an effective mechanism for locating truth, for identifying and expunging falsity, and for increasing the stock of human knowledge."115 It was instantiated in First Amendment

109. See Nat'l Inst. of Family \& Life Advocates v. Becerra, 138 S. Ct. 2361, 2372 (2018) (explaining the Becerra majority's interpretation of when Zauderer applies); see also Zauderer, 471 U.S. at 651 (indicating that the constitutional protections for a right not to provide uncontroversial factual information are minimal).

110. See Becerra, 138 S. Ct. at 2373 (discussing the "professional conduct" exception).

111. See id. at 2376 ("[W]e do not question the legality of health and safety warnings long considered permissible ....").

112. See id. (addressing "uncontroversial disclosures about commercial products").

113. See Rodney A. Smolla, Free Speech in an Open Society 6 (1992) ("The 'marketplace of ideas' is perhaps the most powerful metaphor in the free speech tradition."); see also Daniel J. Solove, The Virtues of Knowing Less: Justifying Privacy Protections Against Disclosure, 53 Duke L.J. 967, 998 (2003) (indicating the marketplace theory pivots on the belief that free speech "contributes to the promotion of truth").

114. See Becerra, 138 S. Ct. at 2374-75 (citing the marketplace theory) ("[W]hen the government polices the content of professional speech, it can fail 'to preserve an uninhibited marketplace of ideas in which truth will ultimately prevail."” (quoting McCullen v. Coakley, 573 U.S. 464, 476 (2014))).

115. Frederick Schauer, Free Speech, the Search for Truth, and the Problem of Collective Knowledge, 70 SMU L. REV. 231, 235 (2017). 
jurisprudence a century ago by Justice Oliver Wendell Holmes, Jr. when he asserted in Abrams $v$. United States ${ }^{116}$ that

when men have realized that time has upset many fighting faiths, they may come to believe even more than they believe the very foundations of their own conduct that the ultimate good desired is better reached by free trade in ideas-that the best test of truth is the power of the thought to get itself accepted in the competition of the market, and that truth is the only ground upon which their wishes safely can be carried out. 117

In its most simplistic_-and perhaps naïve ${ }^{118}$ - formulation, the metaphor invokes "the perfect competition of an idealized neoclassical free market. Bad ideas should be no more feared than bad products or services; they will simply lose out to better competitors, so long as all are freely available." 119 If this is the case, then an interesting question arises for the metaphor's deployment in Becerra: If California's mandate that licensed centers provide true facts to women about the availability of free and low-cost abortions actually expands the speech marketplace and helps pregnant women better know their options, ${ }^{120}$ then how did the majority turn the metaphor against the state?

The answer, it appears, is this: Government intervention in the marketplace of ideas compelling professionals to convey facts about a procedure they disagree with is simply wrong. That is

116. 250 U.S. 616 (1919).

117. Id. at 630 (Holmes, J., dissenting); see also Thomas W. Joo, The Worst Test of Truth: The "Marketplace of Ideas" as Faulty Metaphor, 89 TUL. L. REv. 383, 385 (2014) ("The metaphor can be traced to Justice Holmes's dissent in the 1919 case, Abrams v. United States.").

118. See Lyrissa Lidsky, Nobody's Fools: The Rational Audience as First Amendment Ideal, 2010 U. ILL. L. REV. 799, 826 (2010) ("According to critics, the marketplace of ideas cannot function because a few powerful voices drown out all others. The resulting lack of diversity in public discourse deprives citizen [sic] of the information they need to make rational decisions and denies them their right to participate in policy formation."); see also Smolla, supra note 113, at 6 ("The marketplace of ideas, no less than the marketplace of commerce, will inevitably be biased in favor of those with the resources to ply their wares.").

119. Joseph Blocher, Institutions in the Marketplace of Ideas, 57 DukE L.J. 821, 829-30 (2008).

120. See Nat'l Inst. of Family \& Life Advocates v. Becerra, 138 S. Ct. 2361, 2375 (2018) (stating that California's interest in requiring the licensed notice was "providing low-income women with information about state-sponsored services"). 
because those facts simultaneously dilute the power of the professional's own speech while increasing the odds that patients will adopt the disagreed-with procedure that the government (literally, through funding) sponsors. ${ }^{121}$ That, at least, is one way to unpack the statement by Justice Thomas in Becerra that

when the government polices the content of professional speech, it can fail to "preserve an uninhibited marketplace of ideas in which truth will ultimately prevail." Professionals might have a host of good-faith disagreements, both with each other and with the government, on many topics in their respective fields.... "[T]he best test of truth is the power of the thought to get itself accepted in the competition of the market," and the people lose when the government is the one deciding which ideas should prevail. ${ }^{122}$

A seeming weakness with this logic is that California was not "deciding" for either professionals or patients at licensed centers whether abortion was a good idea or, to borrow Thomas's term, an idea that "should prevail."123 Furthermore, California did not require any viewpoint on the idea of abortion to be conveyed. Instead, it simply compelled transmission of indisputably true facts about abortion services. ${ }^{124}$ Objectively true facts-unlike the subjective idea of whether abortion is a good or bad (morally or medically) procedure-are not subject for debate in the marketplace of ideas. ${ }^{125}$ The facts simply add truthful information to the speech marketplace.

Indeed, as Justice Stephen Breyer wrote for the four-Justice dissent in Becerra, the "marketplace is fostered, not hindered, by providing information to patients to enable them to make fully

121. See id. at 2371 ("By requiring petitioners to inform women how they can obtain state-subsidized abortions-at the same time petitioners try to dissuade women from choosing that option-the licensed notice plainly 'alters the content' of petitioners' speech.").

122. Id. at 2374-75 (internal citations omitted).

123. See id. ("[T] he people lose when the government is the one deciding who should prevail.").

124. See id. at 2379-80 (Breyer, J., dissenting) (quoting CAL. HEALTH \& SAFETY CODE $§$ 123472(a)(1) (West 2018) (showing that California's required disclosure did not require professionals to express a viewpoint regarding abortion)).

125. See id. at 2388 (expressing Breyer's view that the marketplace of ideas is "fostered, not hindered by providing [factual] information to patients to enable them to make fully informed decisions in respect to their pregnancies"). 
informed medical decisions in respect to their pregnancies." 126 Pointing out the key distinction between disputable ideas and incontestable facts, Breyer added that while "[a]bortion is a controversial topic and a source of normative debate," 127 the accessibility "of state resources is not a normative statement or a fact of debatable truth." 128

Justice Thomas's invocation of the marketplace metaphor to support the conclusion that strict scrutiny generally applies when the government compels professionals to convey content-based messages might have been bolstered if he had argued that there are at least two distinct idea marketplaces: One is a mini-marketplace of ideas (the one inside the walls of a licensed crisis pregnancy center) and the other is a macro-marketplace of ideas (the public places and spaces outside the walls of a center). Indeed, the majority had no problem with California conveying facts about low-cost and free abortion services in the latter marketplace. ${ }^{129}$ As Thomas wrote, California was free to "post the information on public property near crisis pregnancy centers." 130 In other words, the government can meddle and intervene all it wants in one marketplace of ideas, but just not in another. The majority, however, failed to explicitly articulate such a bifurcated-marketplace argument. ${ }^{131}$

Turning to the Becerra dissent, which concluded the obligation imposed on licensed centers was "likely constitutional," 132 Justice Breyer initially criticized the majority's overarching logic that because California's law was content-based, then strict scrutiny presumptively applied in the absence of the four exceptions described earlier. ${ }^{133}$ Breyer opined

126. Id.

127. Id.

128. Id.

129. See id. at 2376 (majority opinion) (suggesting that California could have conveyed information about public funding for abortion services via a "public-information campaign").

130. Id.

131. See id. at 2374-76 (discussing the importance of maintaining a free and uninhibited marketplace of ideas but failing to distinguish between the public marketplace and the marketplace inside a licensed pregnancy center).

132. Id. at 2379 (Breyer, J., dissenting).

133. See supra notes 109-112 and accompanying text (describing the four exceptions). 
that this methodology-what he dubbed a "general broad 'content-based' test"134_for determining scrutiny

threatens to create serious problems. Because much, perhaps most, human behavior takes place through speech and because much, perhaps most, law regulates that speech in terms of its content, the majority's approach at the least threatens considerable litigation over the constitutional validity of much, perhaps most, government regulation. Virtually every disclosure law could be considered "content based," for virtually every disclosure law requires individuals "to speak a particular message." 135

This analysis partly reflects Breyer's long-standing rejection of both a rigid, categorical approach to levels of scrutiny ${ }^{136}$ and a First Amendment "jurisprudence of labels."137 Furthermore, it suggests his fondness for a more fluid balancing and proportionality tack. ${ }^{138}$ It also is indicative of Breyer's belief that conduct-or "human behavior,"139 as he put it in Becerra-and speech are often so intertwined that distinguishing between them when it comes to determining scrutiny is injudicious. ${ }^{140}$ But

134. Nat'l Inst. of Family \& Life Advocates v. Becerra, 138 S. Ct. 2361, 2381 (2018) (Breyer, J., dissenting).

135. See id. at 2380 (quoting Justice Thomas's majority opinion).

136. See, e.g., Reed v. Town of Gilbert, 135 S. Ct. 2218, 2234 (2015) (Breyer, J., concurring)

The First Amendment requires greater judicial sensitivity both to the Amendment's expressive objectives and to the public's legitimate need for regulation than a simple recitation of categories, such as "content discrimination" and "strict scrutiny," would permit. In my view, the category "content discrimination" is better considered in many contexts, including here, as a rule of thumb, rather than as an automatic "strict scrutiny" trigger, leading to almost certain legal condemnation.

137. See Pleasant Grove City v. Summum, 555 U.S. 460, 484 (2009) (Breyer, J., concurring) (advocating for a purpose-based approach to the categorization of speech, rather than rigid adherence to forum-based labels).

138. See Donald L. Beschle, No More Tiers? Proportionality as an Alternative to Multiple Levels of Scrutiny in Individual Rights Cases, 38 PACE L. REv. 384, 419 (2018) (observing that Breyer "has shown some enthusiasm for proportionality analysis in his separate opinions"); see also Jamal Greene, The Supreme Court 2017 Term: Foreword-Rights as Trumps? 132 HARV. L. REV. 28, 55 (2018) ("Proportionality and balancing approaches to rights have long found favor with Justice Breyer.”).

139. Becerra, 138 S. Ct. at 2380 (Breyer, J., dissenting).

140. For example, Justice Breyer wrote in 2017 that "virtually all 
Becerra, unlike Reed v. Town of Gilbert, ${ }^{141}$ Expressions Hair Design v. Schneiderman ${ }^{142}$ and Sorrell v. IMS Health Inc., ${ }^{143}$ gave Breyer his first opportunity to put those beliefs into practice in a compelled-speech context.

Thus, Breyer unsurprisingly sounded an alarm in Becerra: If the majority's position takes hold-that in the absence of an exception, strict scrutiny applies to content-based, compelled-speech mandates_it "could radically change prior law, perhaps placing much securities law or consumer protection law at constitutional risk, depending on how broadly its exceptions are interpreted." $144 \mathrm{He}$ fretted that the majority's tack to determining scrutiny might open the metaphorical floodgates of litigation ${ }^{145}$ by providing a battering ram (i.e., strict scrutiny) to attack "ordinary social and economic regulation" 146 and "the mine run of disclosure requirements." 147

government regulation affects speech. Human relations take place through speech.” Expressions Hair Design v. Schneiderman, 137 S. Ct. 1144, 1152 (2017) (Breyer, J., concurring). He thus contended that "it is often wiser not to try to distinguish between 'speech' and 'conduct." Id.

141. See supra note 136 and accompanying text (providing Breyer's relevant sentiment in Reed).

142. See supra note 140 and accompanying text (providing Breyer's relevant sentiment in Schneiderman).

143. 564 U.S. 552 (2011). Foreshadowing his dissent in Becerra, Justice Breyer in Sorrell criticized the notion that strict scrutiny reflexively applies when a statute is content-based, opining that:

To apply a strict First Amendment standard virtually as a matter of course when a court reviews ordinary economic regulatory programs (even if that program has a modest impact upon a firm's ability to shape a commercial message) would work at cross-purposes with this more basic constitutional approach. Since ordinary regulatory programs can affect speech, particularly commercial speech, in myriad ways, to apply a "heightened" First Amendment standard of review whenever such a program burdens speech would transfer from legislatures to judges the primary power to weigh ends and to choose means, threatening to distort or undermine legitimate legislative objectives.

Id. at 584-85 (Breyer, J., dissenting).

144. Becerra, 138 S. Ct. at 2380 (Breyer, J., dissenting).

145. See id. at 2381 (asserting that the majority's content-based test issues an "invitation to litigation").

146. Id.

147. Id. 
Breyer suggested that the majority's decision to constrict the deferential Zauderer rule-an exception to strict scrutiny-only to cases where "disclosures related to the professional's own services or conduct"148 was misguided because "[m]any ordinary disclosure laws"149 do not fit this scenario and thus would confront strict scrutiny review. As an example, he cited a California statute "requiring hospitals to tell parents about child seat belts." 150

Additionally, Breyer blasted Thomas's cursorily tossed-out effort in Becerra to articulate two other exceptions, each noted earlier, to the general rule that strict scrutiny applies in content-based, compelled-speech cases. ${ }^{151}$ Thomas offered those exceptions when he explained that "we do not question the legality of health and safety warnings long considered permissible, or purely factual and uncontroversial disclosures about commercial products." 152

Breyer derisively dubbed this a "generally phrased disclaimer." 153 Beyond the difficulties with it addressed earlier, Breyer contended Thomas's attempt to carve out two more exceptions from heightened review was "more likely to invite litigation than to provide needed limitation and clarification. The majority, for example, does not explain why the Act here, which is justified in part by health and safety considerations, does not fall

148. Id. at 2380. Justice Thomas explained for the Becerra majority that Zauderer was inapplicable because "[t]he notice in no way relates to the services that licensed clinics provide. Instead, it requires these clinics to disclose information about state-sponsored services-including abortion, anything but an 'uncontroversial' topic. Accordingly, Zauderer has no application here." See id. at 2372 (majority opinion) (citing Zauderer v. Office of Disciplinary Counsel, 471 U.S. 626, 651 (1985)); see supra notes 93-97 and accompanying text (describing how the Becerra majority rejected Zauderer's application to the facts in Becerra).

149. Nat'l Inst. of Family \& Life Advocates v. Becerra, 138 S. Ct. 2361, 2380 (2018) (Breyer, J., dissenting).

150. See id. (citing CAL. VeH. CoDE § 27363.5 (a) (West 2013) (requiring hospitals and birthing centers to "provide to and discuss with the parents or the person to whom the child is released, if the child is under eight years of age, information on the current law requiring child passenger restraint systems, safety belts, and the transportation of children in rear seats")).

151. See supra notes 103-104 and accompanying text (identifying these exceptions articulated by Justice Thomas).

152. Becerra, 138 S. Ct. at 2376 (majority opinion).

153. Id. at 2381 (Breyer, J., dissenting). 
within its 'health' category." 154 He also attacked the "absence of a reasoned explanation of the disclaimer's meaning and rationale." 155

So, if the Becerra majority's approach to fathoming the correct level of scrutiny in a compelled-speech case was wrong, then what did Breyer and the dissent suggest was a better methodology? Rather than presume that strict scrutiny applies solely because a law is content-based, Breyer reasoned that the Court should deferentially adopt a "respectful approach to economic and social legislation when a First Amendment claim like the claim present here is at issue." 156

More specifically, in the context of compelled-disclosure cases involving health issues, Breyer suggested the default standard of scrutiny should be akin to rational basis review ${ }^{157}$ and focus on the reasonableness of legislative action. ${ }^{158} \mathrm{He}$ cited Zauderer to support this proposition. ${ }^{159}$ Breyer pointed out that the Court there "refused to apply heightened scrutiny." 160 He also argued that Zauderer was "not so limited," 161 as the Becerra majority claimed, to only cases involving services provided directly by the speaker. ${ }^{162}$

This marks a critical difference from the Becerra majority's approach to scrutiny, because "[w]hile presumptive validity attaches to rational-basis review, a presumption of unconstitutionality attends any form of heightened

154. Id.

155. Id.

156. Id. at 2382 .

157. See supra note 57 (providing an overview of rational basis review).

158. See Becerra, 138 S. Ct. at 2381-82 (outlining the Court's historically deferential approach to evaluating social regulation that relied on the reasonableness of the legislative action to determine whether any speech compelled by the regulation violated the Constitution).

159. See id. at 2382 (citing Zauderer v. Office of Disciplinary Counsel, 471 U.S. 626,651 (1985)).

160. Id. at $2386-87$.

161. Id. at 2387.

162. See id. (pointing out that the rationale behind protecting commercial speech in the first place-namely, to help provide consumers with information-was "not in any way tied to advertisements about a professional's own services"). 
scrutiny-either strict or intermediate."163 In brief, the majority's application of heightened scrutiny causes a content-based, compelled-speech law to become presumptively unconstitutional unless one of four exceptions applies. ${ }^{164}$ Conversely, under the dissent's tack, a content-based, compelled-speech law involving the disclosure of purely factual information is presumptively constitutional.

The dissent's position comports with the notion that the rational basis test is "typically applied to review of economic and social regulations," 165 at least when "there is no discrimination based on a suspect classification or infringement of a fundamental right."166 The First Amendment protection of speech is a fundamental right, ${ }^{167}$ however, so rational basis review typically "plays an extremely limited role in free speech cases." 168 In addition to playing a role in Zauderer, rational basis review also applies to free-speech jurisprudence affecting public school students. ${ }^{169}$

163. Kenneth A. Klukowski, Making Second Amendment Law with First Amendment Rules: The Five-Tier Free Speech Framework and Public Forum Doctrine in Second Amendment Jurisprudence, 93 NEB. L. REV. 429, 463 (2014) (internal citations omitted).

164. See supra notes 109-112 and accompanying text (setting forth the majority's four exceptions to the rule that heightened scrutiny presumptively applies).

165. Nicholas Walter, The Utility of Rational Basis Review, 63 VILL. L. REV. 79,79 (2018).

166. Erwin Chemerinsky, The Rational Basis Test Is Constitutional (and Desirable), 14 Geo. J.L. \& PUB. PoL'y 401, 403 (2016).

167. See Lovell v. Griffin, 303 U.S. 444, 450 (1938) ("Freedom of speech and freedom of the press, which are protected by the First Amendment from infringement by Congress, are among the fundamental personal rights and liberties which are protected by the Fourteenth Amendment from invasion by state action.").

168. Ashutosh Bhagwat, The Test that Ate Everything: Intermediate Scrutiny in First Amendment Jurisprudence, 2007 U. ILL. L. REV. 783, 787 (2007).

169. The Court has concluded that "educators do not offend the First Amendment by exercising editorial control over the style and content of student speech in school-sponsored expressive activities so long as their actions are reasonably related to legitimate pedagogical concerns." Hazelwood Sch. Dist. v. Kuhlmeier, 484 U.S. 260, 273 (1988). As Dean Erwin Chemerinsky notes, this "is the classic phrasing of the rational basis review." Erwin Chemerinsky, The Hazelwooding of the First Amendment: The Deference to Authority, 11 FIRST AMEND. L. REV. 291, 294 (2013). 
Breyer and the dissent contended that Zauderer's deferential test-rather than heightened scrutiny-applies broadly to cases that compel only the disclosure of purely factual, noncontroversial information and that do not force a speaker to convey or adopt a state-sponsored position or opinion on politics, religion, or the nation. ${ }^{170}$ In the dissent's view, this standard is appropriate because the entire rationale for protecting the speech of professionals in commercial settings is to help consumers better understand things and make informed choices. ${ }^{171}$ Put differently, the audience's interest in receiving facts is maximal while the speaker's interest in not conveying them is minimal. ${ }^{172}$

In summary, the Becerra majority and dissent took radically different approaches for determining the applicable level of scrutiny in compelled-disclosure cases and, in doing so, reached drastically different results. The majority's formulaic tack started by considering whether the law was content-based or content-neutral. ${ }^{173}$ After deeming it content-based, ${ }^{174}$ the majority then concluded heightened scrutiny should apply unless the case fit within one of four exceptions. ${ }^{175}$ Because it did not fall within

170. See Nat'l Inst. of Family \& Life Advocates v. Becerra, 138 S. Ct. 2361, 2387 (2018) (Breyer, J., dissenting) (“[W]here a State's requirement to speak 'purely factual and uncontroversial information' does not attempt to 'prescribe what shall be orthodox in politics, nationalism, religion, or other matters of opinion or force citizens to confess by word or act their faith therein,' it does not warrant heightened scrutiny." (quoting Zauderer v. Office of Disciplinary Counsel, 471 U.S. 626, 651 (1985))).

171. See Zauderer, 471 U.S. at 651 (observing that "the extension of First Amendment protection to commercial speech is justified principally by the value to consumers of the information such speech provides").

172. See Becerra, 138 S. Ct. at 2387 (Breyer, J., dissenting)

Whether the context is advertising the professional's own services or other commercial speech, a doctor's First Amendment interest in not providing factual information to patients is the same: minimal, because his professional speech is protected precisely because of its informational value to patients. There is no reason to subject such laws to heightened scrutiny.

173. See id. at 2371 (majority opinion) (discussing how content-based regulations, unlike neutral regulations, target speech based on "communicative content").

174. See id. ("The licensed notice is a content-based regulation of speech.").

175. See supra notes 109-112 and accompanying text (setting forth the majority's four exceptions to the rule that heightened scrutiny presumptively applies). 
those exceptions (including the majority's constricted view of Zauderer), strict scrutiny presumptively applied to the compelled-disclosure mandate at licensed centers. ${ }^{176}$ Adding insult to injury, the majority held that the mandate could not pass muster even under intermediate scrutiny, a lesser standard of heightened review. ${ }^{177}$

The dissent rejected this approach. ${ }^{178}$ Its test for determining if heightened scrutiny applies does not pivot on whether a compelled-speech obligation is content-based. ${ }^{179}$ Instead, it assumes the obligation is content-based. ${ }^{180}$ The dissent then asks whether the compelled message involves "purely factual and uncontroversial information"181 or, instead, whether it "prescribe[s] what shall be orthodox in politics, nationalism, religion, or other matters of opinion or force[s] citizens to confess by word or act their faith therein." 182

If the compelled message consists only of the former speech, then "it does not warrant heightened scrutiny." 183 The government only needs to prove that the message, per Zauderer, is "reasonably related to the State's interest."184 If it involves the latter, then presumably heightened scrutiny applies. ${ }^{185}$ The

176. See Becerra, 138 S. Ct. at 2371 (referring to strict scrutiny as a "stringent standard").

177. See id. at 2375 (explaining that California's licensed notice cannot even survive intermediate scrutiny because the notice is "not sufficiently drawn to achieve" the state's asserted interest of providing low-income women with information about state-sponsored services).

178. See id. at 2380 (Breyer, J., dissenting) (warning that the majority's focus on whether or not speech is content-based "threatens to cause serious problems" as it "threatens considerable litigation over the constitutional validity of much, perhaps most, government regulation").

179. See id. at 2381 (expressing the view that "[p]recedent does not require a test such as the majority's").

180. See id. at 2380 (noting that "[v]irtually every disclosure law could be considered 'content-based"').

181. See id. at 2387 (Breyer, J., dissenting).

182. See id. (quoting W. Va. State Bd. of Educ. v. Barnette, 319 U.S. 624, $642(1943))$.

183. Id.

184. See Zauderer v. Office of Disciplinary Counsel, 471 U.S. 626, 651 (1985) (holding that an advertiser's rights are protected "as long as disclosure requirements are reasonably related to the [s]tate's interest in preventing deception of consumers").

185. Id. 
dissent concluded that the compelled-speech mandate for licensed crisis pregnancy centers about the costs of abortion services fell into the former category because "the availability of state resources is not a normative statement or a fact of debatable truth." 186 The dissent, in turn, considered the speech to be "likely constitutional." 187

With these profoundly divergent approaches to scrutiny in a compelled-speech case-specifically, a compelled-disclosure-offacts case-in mind, the Article next turns to another 2018 Supreme Court decision involving compelled expression, but in a very different context. While the circumstances in the next case, Janus v. American Federation of State, County, \& Municipal Employees, Council 31, are distinct from Becerra, the split over scrutiny and the alignment of the Justices is remarkably consistent.

\section{B. Janus v. American Federation of State, County, \& Municipal Employees, Council 31}

As far as compelled-speech cases go, Janus differs from Becerra in at least three key ways: First, Janus is a two-step compelled-speech case because the law at issue only compelled a monetary contribution, not a direct message. ${ }^{188}$ The monetary contribution, in turn, would be used to support the speech of the labor union to which it was made. ${ }^{189}$ Put differently, Janus is a compelled-subsidy-of-speech case.

Second, Janus did not involve a government-drafted message that had to be conveyed, as was the case in Becerra. ${ }^{190}$ The law, in

186. Nat'l Inst. of Family \& Life Advocates v. Becerra, 138 S. Ct. 2361, 2388 (2018) (Breyer, J., dissenting).

187. Id. at 2379.

188. See Janus v. Am. Fed'n of State, Cty., \& Mun. Emps., Council 31, 138 S. Ct. 2448, 2460 (2018) (noting that under the Illinois statute in question, a non-union member who is a public employee must "pay what is generally called an 'agency fee,' which amounts to a percentage of the union dues").

189. See id. (explaining that the money would "subsidize private speech on matters of substantial public concern").

190. See Becerra, 138 S. Ct. at 2377 (describing California's unlicensed notice as imposing "government-scripted, speaker-based disclosure requirement[s] wholly disconnected from California's informational interest”). 
other words, did not require labor unions to follow a script penned and approved by Illinois lawmakers. ${ }^{191}$ In brief, labor unions did not need to hew to a specific text in using the money-they only had to use the money to support collective bargaining activities on behalf of the people who were compelled to pay it. ${ }^{192}$

A third distinction from Becerra is that Janus was not a compelled-disclosure case. ${ }^{193}$ Janus was not about enhancing citizens' knowledge of their rights to access a state-sponsored program, as was the interest that animated California lawmakers in Becerra. ${ }^{194}$ Rather, Janus involved bolstering a union's ability to speak on behalf of its own members and the non-union employees it was required to represent during bargaining. ${ }^{195}$

Should these differences affect the level of scrutiny to which the compelled-speech laws at issue in Becerra and Janus were subjected? That normative question is now especially important because, ultimately, the conservative majority in Janus-precisely as it had done in Becerra-put the law under the scalpel of heightened scrutiny. ${ }^{196}$ And, as was the case in

191. See Janus, 138 S. Ct. at 2461 (describing how the statute merely directed the union to "provide nonmembers with 'an adequate explanation of the basis for the [agency] fee"').

192. Per the Illinois statute at issue in Janus, agency fees were chargeable to non-union members for union activities including "the costs of the collective bargaining process, contract administration and pursuing matters affecting wages, hours and conditions of employment." 5 ILL. COMP. STAT. 315/6 (e) (2018).

193. See Janus, 138 S. Ct. at 2463-64 (explaining how compelled disclosure "forc[es] free and independent individuals to endorse ideas they find objectionable").

194. See supra notes 67-69 and accompanying text (addressing the legislative intent behind California's compelled-speech mandate at licensed crisis pregnancy centers).

195. See Janus, 138 S. Ct. at 2460 (detailing how unions become employees' designated representative, regardless of whether or not the employees choose to become members).

196. Justice Samuel Alito, writing for the majority in Janus, noted that the dissent "proposes that we apply what amounts to rational-basis review." Janus, 138 S. Ct. at 2465 . Alito bluntly rebuffed that tack, reasoning that "[t]his form of minimal scrutiny is foreign to our free-speech jurisprudence, and we reject it here." Id. The majority instead applied the heightened standard of review known as exacting scrutiny, which it called "a less demanding test" than strict scrutiny. Id. In justifying the application of a heightened standard of review, Alito explained that "because the compelled subsidization of private speech seriously impinges on First Amendment rights, it cannot be casually allowed." 
Becerra, the four-Justice, liberal-bloc dissent adopted a relaxed, deferential level of review in Janus. ${ }^{197}$ In a nutshell, two very different compelled-speech cases were treated in a similarly fractured fashion. ${ }^{198}$

Why did the majority in Janus apply heightened scrutiny? Its discussion of compelled speech sheds much light on that question. Furthermore, coming just one day after the split decision was handed down in Becerra, ${ }^{199}$ the Janus decision illustrates why compelled speech is a doctrine in disarray.

Before delving into the majority's analysis, however, a brief review of the facts is essential. Mark Janus, an Illinois public employee who was not a union member, objected to being forced by state law to pay an agency fee to support the collective bargaining activities of the union designated to exclusively represent him, the American Federation of State, County, and Municipal Employees, Council 31 (“AFSCME”). ${ }^{200}$ Under Illinois

Id. at 2464. See generally R. George Wright, A Hard Look at Exacting Scrutiny, 85 UMKC L. REV. 207 (2016) (providing an overview and critique of the exacting scrutiny test).

197. Writing for the Janus dissenters, Justice Elena Kagan explained that when the government, acting as an employer, regulates an employee's expression related to "the terms and conditions of employment," the Court should treat the government's decisions with "respect-even solicitude." Janus, 138 S. Ct. at 2493 (Kagan, J., dissenting). Under this approach, "the government really cannot lose" because "managerial interests are obvious and strong. And so government employees are ...just employees, even though they work for the government." Id. The Court thus should have applied what Kagan called its "usual deferential approach" akin to the test articulated in Pickering $v$. Board of Education, 391 U.S. 563 (1968). Id. As Kagan interpreted that test, if the regulated "speech is about and directed to the workplace-as contrasted with the broader public square," such as "speech about the terms and conditions of employment - the essential stuff of collective bargaining," then the government wins. Id. at 2495. More bluntly, she added that "[i]f an employee's speech is about, in, and directed to the workplace, she has no "possibility of a First Amendment claim." See id. at 2496 (quoting Garcetti v. Ceballos, 547 U.S. 410, 418 (2006)).

198. Justice Thomas wrote for the Becerra majority joined by Justices Kennedy, Roberts, and Alito with Justice Gorsuch concurring. The dissenting opinion was written by Justice Breyer, joined by Justices Ginsberg, Sotomayor, and Kagan. Likewise, Justice Alito delivered the opinion of the Janus majority, joined by Justices Kennedy, Thomas, Roberts, and Gorsuch.

199. Becerra was decided on June 26, 2018, while Janus was decided on June 27, 2018.

200. Janus v. Am. Fed'n of State, Cty., \& Mun. Emps., Council 31, 138 S. Ct. 2448, 2461-62 (2018). The AFSCME describes itself as 
law, Janus was not required to join a union, but the union selected by his co-workers to represent their unit nonetheless was assigned to serve as Janus's sole representative in collective bargaining with the government of Illinois. ${ }^{201}$ The agency fee-more favorably referred to by the Janus dissent as a "fair-share payment"202_constitutes "a percentage of the union dues" 203 and is designated by statute to cover only "the costs of the collective bargaining process, contract administration and pursuing matters affecting wages, hours and conditions of employment." 204 Mark Janus's agency payment was forbidden by law from being used by his union to cover costs "related to the election or support of any candidate for political office." 205

Janus objected to the positions that the AFSCME took during collective bargaining. ${ }^{206} \mathrm{He}$ believed the union's stances were unwise given the fiscal crisis facing Illinois. ${ }^{207}$ Janus therefore alleged the agency fees were tantamount to "coerced political speech." 208

the nation's largest and fastest growing public services employees union. AFSCME's members provide the vital services that make America happen. We are nurses, corrections officers, child care providers, EMTs, sanitation workers and more. With working members in hundreds of different occupations and retirees across the country, AFSCME advocates for fairness in the workplace, excellence in public services and prosperity and opportunity for all working families.

About AFSCME, AFSCME, https://perma.cc/MM3C-FG6B (last visited Sept. 23, 2019) (on file with the Washington and Lee Law Review).

201. See Janus, 138 S. Ct. at 2460 (describing that unions become a unit's sole representative, regardless of whether or not each employee in the unit chooses to personally become a member).

202. Id. at 2487 (Kagan, J., dissenting).

203. Id. at 2460.

204. 5 Ill. Comp. Stat. 315/ 6(e) (2018).

205. Id. § $315 / 3(\mathrm{~g})$.

206. See Janus, 138 S. Ct. at 2461 (explaining that Mr. Janus opposes several of the public policy positions that the union advocates, including the union's positions on collective bargaining).

207. See id. ("[M]ark Janus believes that the Union's 'behavior in bargaining does not appreciate the current fiscal crises in Illinois and does not reflect his best interests or the interests of Illinois citizens."').

208. Id. at 2462 . 
Janus's framing 209 of the substance of his expression was strategic because political speech lies at the heart of the First Amendment's protection of free expression. ${ }^{210}$ Additionally, linking speech during collective bargaining to a larger financial predicament of a government entity was savvy because it suggested the union's speech constitutes a matter of public concern. ${ }^{211}$ The Supreme Court has made it plain that such expression is privileged in First Amendment jurisprudence. ${ }^{212}$ For example, the Court shielded the speech of Westboro Baptist Church members from tort claims in Snyder $v$. Phelps ${ }^{213}$ because "[their] speech was at a public place on a matter of public concern," and thus, "that speech [was] entitled to "special protection' under the First Amendment." 214

Mark Janus's framing of a public-sector union's speech during collective bargaining with a government entity as constituting political expression and a matter of public concern clearly paid off with the conservative five-Justice majority on the compelled-speech issue. ${ }^{215}$ To wit, the opening paragraph of the

209. See Robert M. Entman, Framing: Toward Clarification of a Fractured Paradigm, 43 J. CoMm. 51, 52 (1993) (asserting that "[t]o frame is to select some aspects of a perceived reality and make them more salient in a communicating text, in such a way as to promote a particular problem definition, causal interpretation, moral evaluation, and/or treatment recommendation for the item described").

210. See Citizens United v. Fed. Election Comm'n, 558 U.S. 310, 340 (2010) ("[P]olitical speech must prevail against laws that would suppress it, whether by design or inadvertence. Laws that burden political speech are 'subject to strict scrutiny,' which requires the Government to prove that the restriction 'furthers a compelling interest and is narrowly tailored to achieve that interest." (quoting Fed. Election Comm'n v. Wis. Right to Life, Inc., 551 U.S. 449, 464 (2007))); see also McIntyre v. Ohio Elections Comm'n, 514 U.S. 334, 347 (1995) ("When a law burdens core political speech, we apply 'exacting scrutiny,' and we uphold the restriction only if it is narrowly tailored to serve an overriding state interest.").

211. See Janus v. Am. Fed'n of State, Cty., \& Mun. Emps., Council 31, 138 S. Ct. 2448, 2477 (2018) (discussing how disagreement between the government and the unions about solutions to Illinois's budget crisis is speech "overwhelmingly of substantial public concern").

212. See, e.g., Snyder v. Phelps, 562 U.S. 443, 451-52 (2011) (emphasizing that speech on matters of public concern is "at the heart" of the First Amendment's protection).

213. 562 U.S. 443 (2011).

214. Id. at 458 .

215. See Janus, 138 S. Ct. at 2475 ("To suggest that speech on such matters is not of great public concern . . . is to deny reality."). 
majority's opinion went so far as to characterize the AFSCME's speech as addressing "matters of substantial public concern." 216 In reaching this characterization, the majority tracked Mark Janus's framing. It latched on to Illinois's financial woes ${ }^{217}$ and concentrated on the notion that both "how public money is spent"218 and the views that unions express on the issues of "education, child welfare, healthcare, and minority rights"219 during collective bargaining are of "great public importance." 220

This classification of speech during collective bargaining between unions and government entities provided an ideal entrée for Justice Samuel Alito, in penning the majority opinion, to suggest that the compelled-speech obligation in Janus was of grave First Amendment concern. ${ }^{221}$ It was not, in other words, a compelled-disclosure case involving purely factual information. ${ }^{222}$ Alito thus cited for support canonical compelled-speech cases noted in this Article's Introduction, including Wooley, Barnette and Tornillo. ${ }^{223}$ In doing so, he reasoned that laws "compelling speech are at least as threatening" 24 as those stopping individuals from speaking. Here, he focused specifically on statutes that would compel individuals to:

216. Id. at 2460 (emphasis added).

217. See id. at 2474-75 (acknowledging that Illinois "suffers from severe budget problems" and that the Governor and public-sector unions "disagree sharply about what to do about these problems").

218. Id. at 2475 .

219. Id.

220. Id.

221. See id. at 2476 (explaining that the importance of the topics unions cover puts their speech in a category of public concern which the Supreme Court has often recognized as occupying "the highest rung of the hierarchy of First Amendment values").

222. See, e.g., Zauderer v. Office of Disciplinary Counsel, 471 U.S. 626, 651 (1985) (concluding that the state was regulating only "purely factual and uncontroversial information" related to the calculation of contingent-fee rates as opposed to "prescib[ing] what shall be orthodox in politics, nationalism, religion, or other matters of opinion or forc[ing] citizens to confess by word or act their faith therein").

223. See cases cited supra notes 7-17 and accompanying text (providing a brief overview of each case).

224. Janus v. Am. Fed'n of State, Cty., \& Mun. Emps., Council 31, 138 S. Ct. 2448, 2464 (2018). 
- "mouth support for views they find objectionable,"225

- "voice ideas with which they disagree;" ${ }^{226}$ and

- "express[] support for a particular set of positions on controversial public issues." 227

In brief, Alito pounded home the point that because Janus was an expression-of-viewpoint mandate, this justified ratcheting up the level of scrutiny because "additional damage is done" beyond that which occurs when the government silences someone. ${ }^{228} \mathrm{He}$ explained that "[f]orcing free and independent individuals to endorse ideas they find objectionable is always demeaning," ${ }^{229}$ and added that "[c]ompelling a person to subsidize the speech of other private speakers raises similar First Amendment concerns." 230

Laws like that in Illinois therefore "cannot be casually allowed" 231 and heightened scrutiny must be applied, at least in the majority's view. ${ }^{232}$ A general rule for scrutiny in compelled-speech cases for the Janus majority thus appears to be this: If a statute, either directly or through a funding-subsidization mandate, compels a person to express a viewpoint she disagrees with on an issue of public concern, then heightened scrutiny applies.

It may be that the Janus dissent also embraces such a general rule, but that it vehemently disagrees with the majority that speech during collective bargaining with the government is a matter of public concern. ${ }^{233}$ Justice Elena Kagan, authoring a dissent joined by Justices Ruth Bader Ginsburg, Stephen Breyer,

\footnotetext{
225. Id. at 2463.

226. Id. at 2464 .

227. Id.

228. Id.

229. Id.

230. Id.

231. Id.

232. See supra note 196 and accompanying text (explaining the majority's decision to apply exacting scrutiny).

233. See Janus, 138 S. Ct. at 2496 (Kagan, J., dissenting) (observing that the Court has previously "rejected all attempts by employees to make a 'federal constitutional issue' out of basic employment matters" (internal citations omitted)).
} 
and Sonia Sotomayor, concluded that such expression is decidedly not a matter of public concern because it is "about the terms of employment: The workplace remains both the context and the subject matter of the expression." 234 An alternative, more narrow and context-specific way of phrasing the dissent's position may be this: If speech is compelled in the context of collective bargaining sessions between a union representing public-sector employees and the government, then a standard of scrutiny approximating rational basis review-not any form of heightened First Amendment scrutiny-is appropriate. ${ }^{235}$

Viewed at a macro level, at least for the Janus majority and from a decidedly pro-First Amendment perspective, being compelled to subsidize the speech of public-sector unions during collective bargaining is equally as wrong as being compelled to pledge allegiance to the United States or to salute the American flag (Barnette) ${ }^{236}$ or being mandated to publicly display a state motto that conflicts with one's religious beliefs (Wooley). ${ }^{237}$ Janus, in brief, fits snugly with the framework of these seminal cases.

The four-Justice dissent, however, flatly rejected such equivalency and offered a very different view of the compelled speech in Janus. ${ }^{238}$ Specifically, Justice Kagan rebuked the majority's reliance on Barnette for the sweeping proposition that "compelling speech always works a greater injury, and so always requires a greater justification." ${ }^{239}$ She suggested that Barnette was an outlier case, calling it "possibly (thankfully) the most exceptional in our First Amendment annals."240

234. Id.

235. See id. at 2494 (advocating for the "usual deferential approach" first articulated in Pickering v. Board of Education, 205, 391 U.S. 563 (1968)).

236. See W. Va. State Bd. of Educ. v. Barnette, 319 U.S. 624, 642 (1943) (concluding that a forced pledge of allegiance "invades the sphere of intellect and spirit which it is the purpose of the First Amendment" to protect).

237. See Wooley v. Maynard, 430 U.S. 705, 715 (1977) (deciding that New Hampshire was not allowed to force citizens to become "mobile billboard[s]" for the state's "ideological message[s]").

238. See Janus v. Am. Fed'n of State, Cty., \& Mun. Emps., Council 31, 138 S. Ct. 2448, 2494 (2018) (Kagan, J., dissenting) ("II]f anything, the First Amendment scales tip the opposite way when (as here) the government is not compelling actual speech, but instead compelling a subsidy that others will use for expression.").

239. Id. (emphasis added).

240. Id. 
Therefore, rather than viewing compelled-speech regulations as presumptively more dangerous than ones silencing expression, Kagan considered them of equal constitutional concern. ${ }^{241}$ Furthermore, she opined that when a case does not directly compel speech but, as in Janus, involves the compelled subsidization of speech, then it actually is of less worry than a statute squelching speech. ${ }^{242}$ In the dissent's view, when the "government mandates a speech subsidy from a public employee ... it should get at least as much deference as when it restricts the employee's speech." 243

In summary, Janus raises key questions about the future of compelled-speech jurisprudence: First and foremost, should compelled-speech laws be viewed as presumptively more dangerous than laws that stop speech, or should they be treated as of equal concern? As suggested above, the majority and dissent are fractured on this issue. ${ }^{244}$

Second and relatedly, is it possible to limit the reach of Justice Alito's assertion that "additional damage is done" 245 when speech is compelled to only situations where the speech being compelled constitutes a viewpoint on an issue of public concern? This limitation may be the case because Alito's two sentences immediately following his additional damage contention read:

In that situation, individuals are coerced into betraying their convictions. Forcing free and independent individuals to endorse ideas they find objectionable is always demeaning, and for this reason, one of our landmark free speech cases said that a law commanding "involuntary affirmation" of objected-to

241. See id. (noting that "the standard First Amendment rule is that the 'difference between compelled speech and compelled silence' is 'without constitutional significance" (quoting Riley $v$. Nat'l Fed'n of the Blind, 487 U.S. $781,796(1988)))$.

242. See id. (opining that "the majority's distinction between compelling and restricting speech ... lacks force" and insisting that the right to speak and the right to refrain from speaking are "complimentary components" of the First Amendment (quoting Wooley, 430 U.S. at 714)).

243. Id. at 2495.

244. See supra note 196 and accompanying text (setting forth the majority's position) and note 197 and accompanying text (setting forth the dissent's position).

245. Janus, 138 S. Ct. at 2464 (majority opinion). 
beliefs would require "even more immediate and urgent grounds" than a law demanding silence. ${ }^{246}$

In other words, might it be that Alito's worry that compelled-speech laws cause more harm does not apply in scenarios factually distinct from Janus, such as cases involving only the compelled disclosure of objective facts like Becerra? Yet even this effort to give Alito's words a constrained reach is muddled because the Becerra majority, in fact, applied heightened First Amendment scrutiny in a compelled-disclosure-of-factual information case. ${ }^{247}$

A third concern is that even if the majority and dissent were to agree that heightened First Amendment scrutiny applies when the government compels a person to express an ideological viewpoint on a matter of public concern, the two sides in Janus could not agree on what constitutes a matter of public concern. ${ }^{248}$ The majority found that speech during collective bargaining sessions between a union and the government is a matter of public concern and importance. ${ }^{249}$ The dissent strenuously disagreed. ${ }^{250}$ In other words, even if a legal standard is agreed upon in certain compelled-speech scenarios, that standard is tremendously problematic if it hinges on whether speech is a matter of public concern because "the line delineating the public and private provinces is anything but bright,"251 thereby affording

246. See id. (emphasis added) (quoting W. Va. State Bd. of Educ. v. Barnette, 319 U.S. 624, 633 (1943)).

247. See supra notes 91-92 and accompanying text (describing how the Becerra majority concluded that the regulation imposed on licensed crisis pregnancy centers failed to pass muster under the heightened standard of review known as intermediate scrutiny).

248. See Janus, 138 S. Ct. at 2495 (Kagan, J., dissenting) ("The question is not, as the majority seems to think, whether the public is, or should be, interested in a government employee's speech. Instead, the question is whether that speech is about and directed to the workplace ....").

249. See id. at 2473 (majority opinion) ("When a large number of employees speak through their union, the category of speech that is of public concern is greatly enlarged, and the category of speech that is of only private concern is substantially shrunk.").

250. See id. at 2496 (Kagan, J., dissenting) (distinguishing speech that is of public concern with speech that is "about, in, and directed to the workplace").

251. Clay Calvert, Defining "Public Concern" After Snyder v. Phelps: A Pliable Standard Mingles with News Media Complicity, 19 VILL. SPORTs \& ENT. L.J. 39, 40 (2012). 
ample legal leeway for the conservative and liberal Justices to reach contrary positions on what is of public concern. The split in Janus makes this abundantly clear.

Ultimately, the majority and dissent were thousands of legal miles apart in their approach to the compelled-speech scenario they confronted in Janus. While the dissent characterized the Illinois statute as a mere "workaday economic and regulatory policy,"252 the majority held that it "seriously impinges on First Amendment rights" 253 and thus "cannot be casually allowed." 254 Such framing, in turn, led them to apply different standards of scrutiny and to reach different outcomes.

\section{Digging Deeper into Justice Thomas's Views on Compelled Speech: His Masterpiece Cakeshop Concurrence}

As noted earlier, Justice Thomas authored the majority opinion in Becerra. ${ }^{255}$ Just a few weeks earlier, in Masterpiece Cakeshop, Ltd. v. Colorado Civil Rights Commission, Thomas elaborated on his views about compelled speech in a concurrence joined by Justice Neil Gorsuch. ${ }^{256}$ Although the Court resolved the case on freedom of religion grounds that avoided the free speech question, ${ }^{257}$ a brief examination of Thomas's Masterpiece Cakeshop concurrence sheds additional light on his and Gorsuch's views about compelled speech.

Thomas suggested in Masterpiece Cakeshop that it makes no difference in compelled-speech cases whether the government is: 1) compelling expression of an opinion or a fact, ${ }^{258}$ or 2)

252. Janus v. Am. Fed'n of State, Cty., \& Mun. Emps., Council 31, 138 S. Ct. 2448, 2501 (2018) (Kagan, J., dissenting).

253. Id. at 2464 (majority opinion).

254. Id.

255. See supra note 26 and accompanying text (identifying the five-Justice Becerra majority).

256. Masterpiece Cakeshop, Ltd. v. Colo. Civil Rights Comm'n, 138 S. Ct. 1719, 1740 (2018) (Thomas, J., concurring in part).

257. See id. at 1724 (majority opinion) ("[T]he Commission's actions here violated the Free Exercise Clause; and its order must be set aside.").

258. See id. at 1742 (Thomas, J., concurring in part) (opining that the First Amendment "applies not only to expressions of value, opinion, or endorsement, but equally to statements of fact the speaker would rather avoid" (internal citations omitted)). 
compelling the "creation, distribution or consumption of the speech." 259 In other words, as to the first facet, it seems Thomas would examine a compelled factual disclosure law under the same level of scrutiny as a law compelling expression of a political opinion. ${ }^{260}$

Additionally, he made it clear that Colorado's public accommodation law compelling Jack Phillips to bake a cake that celebrated a same-sex marriage could only pass muster if it survived strict scrutiny. ${ }^{261}$ In brief, because Thomas believes that "the government cannot compel speech,"262 any mandate to the contrary must survive the Court's highest level of review. This proved to be the case for Thomas in Becerra regarding the compelled-disclosure law for licensed crisis pregnancy centers, although he held there that it was not necessary to apply strict scrutiny because the law failed review under intermediate scrutiny. ${ }^{263}$

In Masterpiece Cakeshop, Thomas reasoned that the Colorado law could not pass muster under strict scrutiny because it was designed to prevent individuals such as Phillips from expressing views that might offend others. ${ }^{264}$ Citing the Court's ruling in the flag-burning case of Texas $v$. Johnson, 265 Thomas explained that "[s]tates cannot punish protected speech because some group

259. Id.

260. See id. at 1745-46 (reasoning that both forms of speech are equally expressive, requiring government regulations limiting either form to survive strict scrutiny).

261. See id. ("Because Phillips' conduct... was expressive, Colorado's public-accommodations law cannot penalize it unless the law withstands strict scrutiny.").

262. Id. at 1745 .

263. See Nat'l Inst. of Family \& Life Advocates v. Becerra, 138 S. Ct. 2361, 2375 (2018) (concluding that because California's law did not apply to other types of clinics, it was "not sufficiently drawn to achieve" its stated mission and therefore could not survive intermediate scrutiny).

264. See Masterpiece Cakeshop, 138 S. Ct. at 1746 (Thomas, J., concurring in part) ("Colorado would not be punishing Phillips if he refused to create any custom wedding cakes; it is punishing him because he refuses to create custom wedding cakes that express approval of same-sex marriage. In cases like this one, our precedents demand 'the most exacting scrutiny."' (internal citations omitted)).

265. 491 U.S. 397, 414 (1989). 
finds it offensive, hurtful, stigmatic, unreasonable, or undignified." 266

Thomas added one other point that merits noting. Specifically, he concluded that allowing a person to issue a disclaimer disavowing the compelled message or disassociating oneself from it does not eliminate the First Amendment free speech issues. ${ }^{267}$ Thomas wrote here that "[ $\left.t\right]$ he Colorado Court of Appeals also erred by suggesting that Phillips could simply post a disclaimer, disassociating Masterpiece from any support for same-sex marriage. Again, this argument would justify any law compelling speech. And again, this Court has rejected it." 268

In brief, Thomas's concurrence in Masterpiece Cakeshop indicates his steadfast unwillingness to give laws that compel speech of any form-be it disclosure of facts or expressions of opinion-a judicial pass under something less than heightened First Amendment scrutiny. The fact that Justice Gorsuch joined him in this concurrence suggests the Trump appointee backs up Thomas in this position.

\section{Conclusion}

This Article exposed fervent disagreement between the Supreme Court's conservative and liberal blocs over the relevant standard of scrutiny for analyzing compelled-speech statutes in two 2018 cases, Becerra and Janus. Of course, if one accepts the "realist thesis that there is more to legal decision-making than the orderly application of positive law generalizations" 269 and acknowledges "the fallacy of the logical form as the source for answers to legal questions," 270 then it is nearly impossible not to contextualize these cases within the broader social and political

266. Masterpiece Cakeshop, 138 S. Ct. at 1746 (Thomas, J., concurring in part).

267. See id. at 1745 (reasoning that the government "cannot 'require speakers to affirm in one breath that which they deny in the next" (internal citations omitted)).

268. Id.

269. Harry W. Jones, Law and Morality in the Perspective of Legal Realism, 61 Colum. L. ReV. 799, 799 (1961).

270. E. Hunter Taylor, Jr., H. L. A. Hart's Concept of Law in the Perspective of American Legal Realism, 35 Modern L. REv. 606, 606-07 (1972). 
frameworks that animate them-abortion ${ }^{271}$ and labor unions. ${ }^{272}$ In other words, it may be that these contentious subjects, which some may view as dividing conservatives and liberals, exacerbated the scrutiny problems in Becerra and Janus. ${ }^{273}$ Perhaps when less polarizing compelled-speech cases come down the legal pike, the Court will be less fractured over scrutiny. That, however, is speculative.

What now is certain is that the Court's conservatives are ready to ratchet up scrutiny in compelled-speech cases involving both the disclosure of objectively true facts (Becerra) and those that ostensibly compel individuals to adopt viewpoints they oppose on issues of public concern (Janus). In the process, they are willing to: 1) narrowly confine the reach of Zauderer, thereby limiting the availability of what amounts to a rational basis test, ${ }^{274}$ and 2) broadly construe, per Janus, what constitutes a matter of public concern, thereby increasing the odds that heightened scrutiny will apply. ${ }^{275}$ For the conservatives-and as the title of this Article states-Zauderer withers while heightened scrutiny blossoms. Moreover, Justice Thomas's concurrence in Masterpiece Cakeshop, which was addressed in Part II, only buttresses this stance.

Conversely, the Court's liberals want to apply the equivalent of rational basis review in compelled-speech cases involving the: 1) compelled disclosure of only purely factual, uncontroversial information (Becerra), ${ }^{276}$ and 2) compelled-subsidization of public-sector union speech where money is expended only on expression affecting collective bargaining with the government

271. Becerra, 138 S. Ct. at 2361.

272. Janus v. Am. Fed'n of State, Cty., \& Mun. Emps., Council 31, 138 S. Ct. 2448 (2018).

273. See id. at 2459 (showcasing an ideological split between the conservative majority and the liberal dissenters); Becerra, 138 S. Ct. at 2367 (same).

274. See supra notes 93-97 and accompanying text (addressing the Becerra majority's efforts to limit the scope of the rule from Zauderer).

275. See supra notes 216-219 and accompanying text (addressing the Janus majority's characterization of the speech that occurs during collective bargaining between a public-sector union and a governmental entity).

276. See supra note 170 and accompanying text (discussing Justice Breyer's view that the compelled-disclosure mandate in Becerra does "not warrant heightened scrutiny"). 
(Janus). ${ }^{277}$ The first facet reflects a broad interpretation of Zauderer, not limiting it to situations involving disclosure of facts about goods or services offered directly by the individual or entity being compelled to speak. ${ }^{278}$ The second embraces a deferential approach to what Justice Kagan termed "workaday economic and regulatory policy." 279

Given the wide range of contexts in which right-not-to-speak claims may arise, ${ }^{280}$ it is doubtful that a single, one-size-fits-all approach for determining scrutiny will be sufficiently nuanced and nimble to account for all situations. Simply presuming that if a compelled-speech law is content-based, then strict scrutiny applies, is a decidedly blunt and sweeping approach. Why? Because, as Justice Breyer suggested in Becerra, "much, perhaps most, law regulates . . . speech in terms of its content." 281

On the other hand, presuming that rational basis review applies if the Justices frame a case not as about speech, but instead as addressing, per the Becerra dissent, "ordinary economic and social legislation," 282 or, as the Janus dissent put it, "workaday economic and regulatory policy," 283 is also troublesome. What one group of Justices might classify as a case about economic and social legislation, another might perceive it-to use Justice Thomas's phrase in Becerra-as involving a full-scale "speech as speech" 284 dispute.

277. See supra notes 236-241 and accompanying text (summarizing Justice Kagan's argument for applying a more relaxed, deferential standard of review in Janus).

278. See Nat'l Inst. of Family \& Life Advocates v. Becerra, 138 S. Ct. 2361, 2387 (2018) (Breyer, J., dissenting)

The majority concludes that Zauderer does not apply because the disclosure in no way relates to the services that licensed clinics provide'. . . . But information about state resources for family planning, prenatal care, and abortion is related to the services that licensed clinics provide ... . Regardless, Zauderer is not so limited.

279. Janus, 138 S. Ct. at 2501 (Kagan, J., dissenting).

280. See cases cited supra notes 7-19 and accompanying text (discussing right-not-to-speak Supreme Court cases in a variety of social, political, and religious contexts).

281. Becerra, 138 S. Ct. at 2380 (Breyer, J., dissenting).

282. Id. at 2381 .

283. Janus v. Am. Fed'n of State, Cty., \& Mun. Emps., Council 31, 138 S. Ct. 2448, 2501 (2018) (Kagan, J., dissenting).

284. Becerra, 138 S. Ct. at 2374 (majority opinion). 
Therefore, rather than adopting a rather reductionist formula for fathoming the correct standard of scrutiny in compelled-speech cases, one might articulate multiple criteria or variables for courts to consistently and holistically consider during the scrutiny determination. Using variants of some of the labels noted in Part II, Section A, ${ }^{285}$ these factors might include analysis of:

1) Whether a law compels a speaker to express or embrace a subjective viewpoint with which she disagrees on any given topic or, alternatively, whether it compels conveyance of objectively true facts that are reasonably related to a speaker's goods or services. ${ }^{286}$ The former type of compulsion militates in favor of a higher level of scrutiny than the latter, per the collective logic of Barnette, Wooley, and Zauderer.

2) Whether the legislative intent of a law is to enhance the overall amount of information in the marketplace of ideas that is reasonably related to the speaker's goods or services so that recipients of the speech can make better informed choices (knowledge-enhancement rationale) or, instead, whether the intent is to prevent deception by private speakers that otherwise would be reasonably likely to arise in the absence of the compelled speech (prevention-of-deception rationale), akin to Zauderer's interest in preventing deception about contingency fee arrangements. $^{287}$ A law premised on the former, knowledge-enhancement rationale arguably merits analysis under a higher level of scrutiny because the government is not merely attempting to thwart deception by private actors but is actively intervening to add separate information that it feels is essential. ${ }^{288}$ In other words, the knowledge-enhancement justification gives the state power to tilt the marketplace of

285. See discussion supra Part II.A (providing a brief overview of labels used to characterize compelled-speech laws).

286. See supra notes 124-128 and accompanying text (discussing the "objectively true facts" label).

287. See supra notes 79-81 and accompanying text (discussing the "knowledge-enhancement" and "prevention-of-deception" rationales).

288. See supra notes 79-81 and accompanying text (suggesting that there is a difference between a governmental interest in curbing the spread of false, misleading information and an interest in sending its own message to the public). 
ideas-not simply correct it-with information it believes is important.

3) Whether conveyance of the compelled speech significantly harms the ability of the speaker to effectively and clearly convey a political, moral, or religious belief, ${ }^{289}$ or alternatively, whether it detrimentally affects only the economic and fiscal interests of the speaker. This distinction is grounded in the Court's view that it "is wrong to equate the judicial review applicable to the regulation of a constitutionally protected personal liberty with the less strict review applicable where . . economic legislation is at issue." 290 The former type of compelled-speech mandate should require greater scrutiny because it affects a person's beliefs and values, not simply his or her pocketbook. This factor is also suggested by Becerra, where the effectiveness of crisis pregnancy centers to convey their anti-abortion message and thereby influence women to carry a baby to term was arguably diminished by having to convey information that abortions were available at little to no cost. ${ }^{291}$ Those financial facts about abortions might steer some women toward abortions and away from the speaker's pro-life position. Put differently, this factor entails consideration of the message-diluting or message-adulterating impact of the compelled-speech regulation. ${ }^{292}$

4) Whether the compelled-speech regulation is intended to bring health and safety benefits for the audience that receives it. If that is the legislative intent, the Court must consider actual

289. See, e.g., Wooley v. Maynard, 430 U.S. 705, 707 (1977) (involving government-mandated license plates that were "repugnant to [some residents'] moral and religious beliefs").

290. Whole Women's Health v. Hellerstedt, 136 S. Ct. 2292, 2309 (2016).

291. See Nat'l Inst. Of Family \& Life Advocates v. Becerra, 138 S. Ct. 2361, 2371 (2018)

[L]icensed clinics must provide a government-drafted script about the availability of state-sponsored services, as well as contact information for how to obtain them. One of those services is abortion-the very practice that petitioners are devoted to opposing. By requiring petitioners to inform women how they can obtain state-subsidized abortions - at the same time petitioners try to dissuade women from choosing that option-the licensed notice plainly "alters the content" of petitioners' speech.

292. See supra notes 82-84 and accompanying text (discussing the "message-diluting" rationale). 
evidence suggesting tangible health and safety benefits of the legislation like in Whole Women's Health $v$. Hellerstedt, ${ }^{293}$ where the Court placed "considerable weight upon evidence and argument presented in judicial proceedings" 294 regarding the alleged health and safety benefits to women of two Texas laws ${ }^{295}$ limiting access to abortions. The Court struck down the laws partly because they provided "few, if any, health benefits for women." 296 In brief, if a health-and-safety argument is made in favor of compelling speech, then the Court should apply a level of scrutiny that requires examining the evidence that ostensibly supports that argument.

These, of course, are merely preliminary suggestions of criteria for judicial use when determining the level of scrutiny in compelled-speech cases. They are not meant to be exclusive of other variables or factors. Furthermore, they are offered here solely as springboards for academic and judicial debate and consideration.

Regardless, however, of whether the Court ignores, rejects, or adopts them, it is crucial for the Justices to better define and then consistently apply at least some concrete variables for deciding the correct level of scrutiny in compelled-speech cases. Doing so would add predictability and rigor to this now confusing facet of First Amendment jurisprudence that has sprawled since Barnette was handed down more than seventy-five years ago. ${ }^{297}$ Moreover, it might bolster the Court's legitimacy ${ }^{298}$ - something likely damaged by the contentious confirmation hearings in 2018

\footnotetext{
293. 136 S. Ct. 2292, 2309 (2016).

294. Id. at 2310 .

295. One law required physicians who perform abortions to have admitting privileges at a hospital within thirty miles of the facility where they perform abortions. Id. at 2300. The second statute required facilities that perform abortions to have the same medical equipment necessary to be classified as an ambulatory surgical center. $I d$.
}

296. Id. at 2298.

297. See supra notes 20-25 and accompanying text (detailing the historical-and often confusing-evolution of Supreme Court right-not-to-speak jurisprudence).

298. Legitimacy here refers to what Justice Elena Kagan recently described as the public perceiving that the Court's "decision-making has a kind of integrity to it" and believing that the Court is "not simply just an extension of politics.” Robert Barnes \& Carol D. Leonnig, Partisan Mud Could End Up Tarnishing High Court's Halo, Wash. Post, Sept. 30, 2018, at A8. 
for Justice Brett Kavanaugh ${ }^{299}$ _that is further sapped when it fractures along perceived political lines. Such fracturing, as this Article made evident, is precisely what happened in the compelled-speech cases of Becerra and Janus, ${ }^{300}$ leaving the Court's jurisprudence in this realm both disorderly and partisanly pliable.

299. See, e.g., Megan McArdle, There Is No Cleaning Up This Kavanaugh Mess, Wash. Post, OCT. 7, 2018, AT A23 ("Putting Kavanaugh on the Court under these circumstances has outraged the left half of the political spectrum and undermined the already shaky legitimacy of the Court, and it will touch off a political firestorm if Kavanaugh becomes the fifth vote to overturn Roe $v$. Wade."); Jason L. Riley, Upward Mobility: Democrats Rage Against the Judiciary, Wall ST. J., Oct. 10, 2018, at A17 (quoting U.S. Senator Dianne Feinstein, a Democrat from California, for the proposition that Brett Kavanaugh's confirmation "undermines the legitimacy of the Supreme Court").

300. See supra note 273 and accompanying text (noting the glaring partisan divide between the majority and the dissent in Becerra and Janus). 